What is the Role of Firm-Specific Pay Policies on the Gender Earnings Gap in Canada?

JIANG LI

BENOIT DOSTIE

GAËLLE SIMARD-DUPLAIN 


\section{$\checkmark$ CIRANO Knowledge into action}

Center for Interuniversity Research and Analysis on Organizations

The purpose of the Working Papers is to disseminate the results of research conducted by CIRANO research members in order to solicit exchanges and comments. These reports are written in the style of scientific publications. The ideas and opinions expressed in these documents are solely those of the authors.

Les cahiers de la série scientifique visent à rendre accessibles les résultats des recherches effectuées par des chercheurs membres du CIRANO afin de susciter échanges et commentaires. Ces cahiers sont rédigés dans le style des publications scientifiques et n'engagent que leurs auteurs.

CIRANO is a private non-profit organization incorporated under the Quebec Companies Act. Its infrastructure and research activities are funded through fees paid by member organizations, an infrastructure grant from the government of Quebec, and grants and research mandates obtained by its research teams.

Le CIRANO est un organisme sans but lucratif constitué en vertu de la Loi des compagnies du Québec. Le financement de son infrastructure et de ses activités de recherche provient des cotisations de ses organisations-membres, d'une subvention d'infrastructure du gouvernement du Québec, de même que des subventions et mandats obtenus par ses équipes de recherche.

\section{CIRANO Partners - Les partenaires du CIRANO}

Corporate Partners - Partenaires corporatifs

Autorité des marchés financiers

Bank of Canada

Bell Canada

BMO Financial Group

Business Development Bank of Canada

Caisse de dépôt et placement du Québec

Desjardins Group

Énergir

Hydro-Québec

Innovation, Science and Economic Development Canada

Intact Financial Corporation

Manulife Canada

Ministère de l'Économie, de la Science et de l'Innovation

Ministère des finances du Québec

National Bank of Canada

Power Corporation of Canada

PSP Investments

Rio Tinto

Ville de Montréal

Academic Partners - Partenaires universitaires

Concordia University

École de technologie supérieure

École nationale d'administration publique

HEC Montréal

McGill University

National Institute for Scientific Research

Polytechnique Montréal

Université de Montréal

Université de Sherbrooke

Université du Québec

Université du Québec à Montréal

Université Laval

CIRANO collaborates with many centers and university research chairs; list available on its website. Le CIRANO collabore avec de nombreux centres et chaires de recherche universitaires dont on peut consulter la liste sur son site web.

(C) December 2020. Jiang Li, Benoit Dostie, Gaëlle Simard-Duplain. All rights reserved. Tous droits réservés. Short sections may be quoted without explicit permission, if full credit, including (C) notice, is given to the source. Reproduction partielle permise avec citation du document source, incluant la notice ().

The observations and viewpoints expressed in this publication are the sole responsibility of the authors; they do not necessarily represent the positions of CIRANO or its partners. Les idées et les opinions émises dans cette publication sont sous l'unique responsabilité des auteurs et ne représentent pas nécessairement les positions du CIRANO ou de ses partenaires. 


\title{
What is the Role of Firm-Specific Pay Policies on the Gender Earnings Gap in Canada? *
}

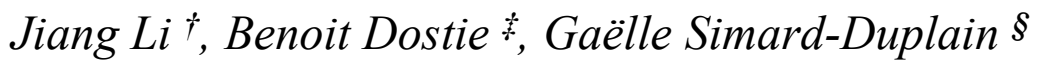

\begin{abstract}
Résumé
Using data from the Canadian Employer-Employee Dynamics Database between 2001 and 2015, we examine the impact of firms' hiring and pay-setting policies on the gender earnings gap in Canada. Consistent with the existing literature and following Card, Cardoso, and Kline (2016), we find that firm-specific premiums explain nearly one quarter of the $26.8 \%$ average earnings gap between female and male workers. On average, firms' hiring practices - due to difference in the relative proportion of women hired at high-wage firms, or sorting - and pay-setting policies due to differences in pay by gender within similar firms - each explain about one half of this firm effect. The compositional difference between the two channels varies substantially over the life-cycle, by parental and marital status, and across provinces.
\end{abstract}

Keywords/Mots-clés: Gender Wage Gap, Firm Effects, Marital Status, Linked EmployerEmployee Data, Pay-Setting, Sorting

JEL Codes/Codes JEL: J16, J31，J51，J71

\footnotetext{
* A shorter version of this paper is available under the same title under Catalogue no. 11F000019M -No. 456 from Statistics Canada Analytical Studies Branch Research Paper Series. We are grateful to Wendy Cukier, Marie Drolet, René Morrissette, and Nicole Yaansah for their helpful comments and suggestions. We would also like to thank the reviewers from Women and Gender Equality Canada for their comments. Jiang Li acknowledges funding from Women and Gender Equality. Benoit Dostie and Gaëlle Simard-Duplain acknowledge funding from the Productivity Partnership as supported by the Social Sciences and Humanities Research Council of Canada (SSHRC). The views expressed herein are those of the authors and do not necessarily reflect the views of Statistics Canada.

$\dagger$ Statistics Canada.

* Corresponding author. benoit.dostie@hec.ca, Department of Applied Economics, HEC Montréal. CIRANO.

$\S$ Centre for Innovative Data in Economics Research (CIDER), University of British Columbia.
} 


\section{INTRODUCTION}

Convergence in the economic outcomes of women and men has slowed down since the 1990s (Kunze (2018); Olivetti and Petrongolo (2016)). The nature of the gender earnings gap has also shifted: it is no longer associated with disparities in human capital, but rather largely attributed to the sorting of female and male workers into different occupations, industries, and firms (e.g., Blau and Kahn (2017); Olivetti and Petrongolo (2016)). Correspondingly, a renewed focus of the research is on the role of the firm or the workplace in explaining what is left of the gender earnings gap.

A bulk of recent studies show that women and men sort into firms that vary in pay and non-pay attributes; and that at a given firm, women and men differ in their ability or willingness to access better paid positions (e.g., Jewell, Razzu, and Singleton (2020); Bertrand, Black, Jensen, and Lleras-Muney (2019); Barth, Kerr, and Olivetti (2017); Datta Gupta and Eriksson (2012); Amuedo-Dorantes and De la Rica (2006)). Among other things, whether the remaining gender earnings gap stems primarily from a "glass door" or a "glass ceiling" effect leads to potentially very different policy implications (Pendakur and Woodcock (2010)).

Most of this literature exploits linked employer-employee data and builds on the canonical model used by Abowd, Kramarz, and Margolis (1999) to study the role of firms in setting their workers' wages. For example, using such data from 2000s Portugal, Card, Cardoso, and Kline (2016) estimate that firm effects explain $21 \%$ of the gender wage gap. They further decompose this contribution into a sorting and a pay-setting component. The sorting component measures the degree to which male and female workers sort into different types of firms; the pay-setting component measure the degree to which male and female workers are paid differently by a given firm. They find that approximately three quarters of this effect operates through the sorting of women and men into different types of firms. The relative importance of sorting has also been documented in other countries in Europe (Bruns (2019); Casarico and Lattanzio (2019); Coudin, Maillard, and Tô (2018)), as well as in South America (Cruz and Rau (2017); Morchio and Moser (2019)).

In this paper, we investigate the relative importance of workers' sorting and firms' pay-setting practices in explaining the gender earnings gap in Canada. We apply the methodology developed by Card, Cardoso, and Kline (2016), using data from the Canadian Employer-Employee Dynamics Database (CEEDD) - a linked administrative data set covering all individual workers and their employers filling corporate tax returns since 2001. The analysis relies on the possibility to observe individual workers over time 
and across firms. It also exploits key variables on workers (e.g., annual earnings, age, sex, and province of residence), their families (e.g., marital status and presence and age of children), and the firms they work for (e.g., industry and firm size).

Our contribution is threefold. First, we add to the budding literature on the relative importance of sorting and pay-setting in firms' contribution to the gender earnings gap. Our results show that firm-specific pay premiums explain nearly one quarter of the $26.8 \%$ gender earnings gap in Canada, in line with existing research. We find that workers' sorting and firms' pay-setting practices each explain approximately one half of that effect. Interestingly, this implies that firms' pay-setting policies play a larger part in Canada compared with other studied countries.

Second, our data allows us to investigate the role of firms separately for people who differ in terms of their marital status. As such, we add to the limited evidence on the factors that drive the relative importance of the sorting and pay-setting channels. Researchers have documented the increased importance of the sorting channel over the life-cycle, as well as the greater role it plays among parents than among non-parents. Although cautiously, these comparisons have typically been interpreted as evidence in line with the differential sorting of women and men into jobs with different pay and non-pay attributes, and the relative value of these attributes for mothers and fathers.

We find that sorting is most important among married workers, and least important among single individuals. Although this may in part be related to the life-cycle patterns discussed above, we find substantial differences in sorting between legally married people and those in common-law unions. This suggests that living arrangements interact with the role of firms in the gender earnings gap, beyond mechanisms associated with the presence of children. The relationship between marital status, intra-household resource allocation, and women's labour supply is well documented in the literature (e.g., Chiappori, Fortin, and Lacroix (2002); Goussé and Leturcq (2018); Stevenson (2007); Voena (2015)). However, ours is the first paper to show that household dynamics may be associated with differences in access to firm premiums.

Finally, we contribute what we believe is important nuance to cross-country comparisons of the relative roles of the sorting and pay-setting channels. These comparisons have informed part of the literature's understanding of what drives these mechanisms. For example, in France and 1990s Germany respectively, Coudin, Maillard, and Tô (2018) and Bruns (2019) have attributed the limited role of firm pay-setting policies to the strength of minimum wage and collective pay-setting institutions. We replicate our results for Canada's three largest provinces, which together make up approximately three quarters of its work force. Whereas international comparisons are complicated by 
differences in the data sets used, the cultural context, and the institutions that directly and indirectly affect labour market participation among women and men, Canadian provinces share a lot of these features.

In our provincial comparisons, we show that firm pay-setting policies are most important in Québec, where they account for $63.5 \%$ of firms' contribution to the gender earnings gap. Notably, Québec is also the province where collective bargaining institutions are strongest, which nuances the interpretation that's been given so far for the relative importance of the pay-setting channel. Second, we also find that interprovincial differences in the strength of the sorting channel are more pronounced among non-parents - compared to parents - and even more so among single individuals. This is of particular interest, provided that much of the existing discussion around the role played by sorting has focused on parents. That is, while the importance of sorting increases as children are born and families expand, firms also contribute to the pay gap among non-parents and among single individuals, in ways that result in substantial variation within Canada.

The rest of this study is organized as follows: Section 2 reviews the literature. Section 3 outlines the analytical framework. Section 4 describes the data and presents descriptive statistics. Section 5 presents our main results with respect to the importance of firm effects and the contributions of the sorting and pay-setting effects. Section 6 discusses how those vary along the life-cycle and between marital statuses. Section 7 moves on to interprovincial differences, and Section 8 concludes.

\section{LiterATURE}

The 20th century has been marked by large improvements in the economic outcomes of women living in high-income countries. However, the past few decades have seen a slowdown in the convergence of female and male outcomes. This fact is well documented, along with the reduced role that Mincerian human capital variables such as education and job tenure play in explaining the remaining - and persisting - gender pay gap. ${ }^{1,2}$

Canada is no exception. The ratio of female-to-male earnings increased from 0.60 to 0.67 between 1970 and 1990, but has been relatively stable around 0.70 since the early

\footnotetext{
${ }^{1}$ Research has often relied on decomposition methods, such as the Oaxaca-Blinder decomposition, to document the factors associated with the gender gap and with changes in the gap. For reviews of this extensive literature, see Kunze (2018) and Olivetti and Petrongolo (2016)

${ }^{2}$ Although disparities in human capital no longer explain differences in the average pay of women and men, research has found that they are relevant at some points of the skill/income distribution (e.g., Blau and Kahn (2017); Boudarbat and Connolly (2013); Kassenboehmer and Sinning (2014)).
} 
1990s (Baker, Benjamin, Desaulniers, and Grant (1995); Baker and Drolet (2010)). Progress in the relative wages of women continued into the early 2000s, but plateaued after reaching 0.86 in the mid-2000s (Baker and Drolet (2010); Pelletier and Moyser (2019)). Furthermore, Pelletier and Moyser (2019) show that very little of the remaining gap can be explained by differences in human capital between Canadian women and men. In fact, they estimate that women's greater education level and job tenure decreased the 2018 gender pay gap by 6.1 percentage points. This contrasts with the important role these factors played in improving relative female outcomes in the 1980s and 1990s (Drolet (2011); Morissette and Lu (2013); Pelletier and Moyser (2019)).

Notwithstanding these changes, the differential sorting of women and men into lowerpaying occupations, industries, and firms continues to explain a substantial portion of the gender pay gap everywhere (e.g., Blau and Kahn (2017); Olivetti and Petrongolo (2016)). In the Canadian context, men's sorting into higher-wage sectors, like construction, manufacturing, and mining, quarrying, and oil and gas extraction, explains nearly 40\% of the 2018 gender gap (Pelletier and Moyser (2019)). Moreover, women are more likely to work for lower-paying firms, including for non-profit organizations and for firms with large proportions of part-time employees (Drolet (2002); Drolet and Mumford (2012); Javdani (2015)).

In this context, the growing availability of large linked employer-employee data sets has supported increasingly refined assessments of gender segregation across firms, of gender disparities within firms, and of the relative importance of between- and withinfirm mechanisms. ${ }^{3}$ In this vein, Card, Cardoso, and Kline (2016) decompose the contribution of firm premiums to the gender wage gap into what they refer to as sorting and bargaining (or pay-setting) effects. To do so, they estimate separate wage equations for women and men, with non-nested worker and firm fixed effects. ${ }^{4}$ Their decomposition captures the fact that women and men may be unequally distributed across firms with different premiums (sorting effect), and may capture a different share of the firm-specific surplus (bargaining effect). Using a large administrative data set on

\footnotetext{
${ }^{3}$ Examples of studies on gender segregation across firms include Bayard, Hellerstein, Neumark, and Troske (2003); Gupta and Rothstein (2005); Jewell, Razzu, and Singleton (2020); Meyersson Milgrom, Petersen, and Snartland (2001); and Sin, Stillman, and Fabling (2017). For gender disparities between firms, see Bertrand, Black, Jensen, and Lleras-Muney (2019); Datta Gupta and Eriksson (2012); Del Bono and Vuri (2011); Heinze and Wolf (2010) and Hensvik (2014). About the relative importance of between- and with firm mechanisms, see Amuedo-Dorantes and De la Rica (2006); Barth, Kerr, and Olivetti (2017); and Pendakur and Woodcock (2010).

${ }^{4}$ Card, Cardoso, and Kline (2016) build on Abowd, Kramarz, and Margolis (1999), who show that employers contribute to wage differentials across workers, beyond what can be explained based on the latter's observed and unobserved individual-level characteristics (see also Abowd, Creecy, and Kramarz (2002)).
} 
private-sector workers from Portugal, they find that $20.9 \%$ of the gender wage gap in the early 2000s can be attributed to firm effects. Approximately three quarters of this firm-specific pay premium results from the sorting of women into lower-paying firms, with the remainder stemming from gender disparities in bargaining.

Subsequent work has produced comparable results for other countries, with the portion of the gender pay gap attributable to firm effects ranging from $8 \%$ in France (Coudin, Maillard, and Tô (2018)) and 11\% in 1990s West Germany (Bruns (2019)) to nearly 50\% in Chile (Cruz and Rau (2017)) and 60\% in Brazil (Morchio and Moser (2019)). In addition to Portugal, mid-range countries include 2000s West Germany (Bruns (2019)), Italy (Casarico and Lattanzio (2019)), and Estonia (Masso, Meriküll, and Vahter (2020)), where respectively 25.9, 30.5\%, and $35.1 \%$ of the gender pay gap is attributable to firm effects. Common to almost all of these studies is the central role played by sorting. Depending on the country considered, it is estimated to account for 15.0 to $34.7 \%$ of the gender pay gap, explaining at least $70.0 \%$ of the firm effect. $^{5}$ Relying on different methodologies, Jewell, Razzu, and Singleton (2020) and Sorkin (2017) also find that sorting plays an important role in the United States and the United Kingdom: it accounts respectively for 16.1 and $27.8 \%$ of the overall gender gap.

Knowing the relative importance of sorting and bargaining is valuable insofar as it can be used to learn about the mechanisms that contribute to the gender pay gap, and to design policy accordingly. Research in that respect is still in its very early stages. For the most part, it has relied on comparisons across demographic groups to draw tentative conclusions about the forces that may be at play, and on informal cross-country comparisons of the institutional setting that impact the labour market directly and indirectly.

Card, Cardoso, and Kline (2016) observe that the sorting channel gains in importance as women age, beginning in their early 30s. Building on this finding, Coudin, Maillard, and Tô (2018) show that sorting increases after childbirth among French women, an effect that is not driven by age. They also find that mothers are more likely to work in firms closer to their home or in firms which offer more flexible hours. In line with this, Bruns (2019) estimates that sorting into lower-paying firms accounts for at least a quarter of the wage penalty associated with motherhood. This effect is driven by mothers who change job following childbirth.

\footnotetext{
${ }^{5}$ The only exception is Estonia, for which Masso, Meriküll, and Vahter (2020) find that sorting accounts only for approximately half of the firm-specific pay premium.
} 
These findings are consistent with research that has documented the pay penalties associated with such things as shorter and/or more flexible work schedules, and women's sorting into these kinds of work arrangements (Bertrand, Goldin, and Katz (2010); Cortés and Pan (2019); Goldin (2014); Goldin and Katz (2016); Le Barbanchon, Rathelot, and Roulet (2020)). It is also in line with findings from the experimental literature suggesting that women have greater preferences for job flexibility than men (e.g., Wiswall and Zafar (2018)).

In recent work, Morchio and Moser (2019) exploit flows in and out of firms to draw conclusions on female and male workers' preferences for different firms. They also conclude that women value non-pay firm attributes more than men, particularly flexible work hours and parental leave benefits. However, they estimate that compensating differentials explain only $18 \%$ of the gender pay gap, whereas employer taste-based discrimination and gender-specific hiring costs play a bigger role in driving gender segregation.

The emphasis on the distinction between women with and without children is not surprising, given the large literature that documents the substantial impact childbirth and childrearing have on women's labour market participation (Angelov, Johansson, and Lindahl (2016), Kleven, Landais, Posch, Steinhauer, and Zweimüller (2021)). However, differences have been observed across other dimensions as well; for example, across the skill distribution. Card, Cardoso, and Kline (2016) document the greater importance of bargaining for higher-educated workers, while Bruns (2019) finds that bargaining only affects individuals at the top of the earnings distribution.

Parallel to the comparisons authors have drawn between different demographic groups, researchers have discussed the potential role of institutions in determining the relative importance of the sorting and bargaining channels. Bruns (2019) links the growing importance of firm effects in explaining the gender wage gap in West Germany to the decline of unionization and the decentralization of collective bargaining. While the gender pay gap in West Germany has also been relatively stable since the mid-1990s, bargaining contributed to reducing the gap in the 1995-2001 period. In line with this, Coudin, Maillard, and Tô (2018) attribute the limited role of firms in France to the large minimum wage and to the structure of collective agreements. Both factors are consistent with the very particular role the authors find for bargaining. Whereas bargaining has been found to account for at least $25 \%$ of the firm's role in the gender gap in other countries where similar analyses have been conducted, Coudin, Maillard, and Tô (2018) estimate that it contributes to reducing the gap in the overall population. 


\section{EMPIRICAL MODEL}

Our model follows the well-known Abowd, Kramarz, and Margolis (1999) (AKM) linear model with non-nested worker and firm fixed effects. Our dependent variable is the worker's annual earnings. A concern associated with annual earnings is that they incorporate both wages and work intensity (number of hours and weeks of work). To extrapolate our results to represent earning differentials between men and women, we apply a full-time equivalent income threshold to select our analysis sample. We discuss the sample selection procedure in more detail in the next section.

Let $y_{i t}$ represent yearly earnings for worker $i$ in firm $j$ in year $t$. The complete econometric specification is given by equation (3.1):

$$
\ln y_{i t}=\alpha+\beta X_{i t}+\theta_{i}+\psi_{j(i, t)}+\epsilon_{i t},
$$

where $\alpha$ is a constant, $\theta_{i}$ is a time-invariant worker-specific effect, $\psi_{j(i, t)}$ is a timeinvariant firm-specific effect for firm $j$ where worker $i$ is employed at time $t$, and $\epsilon_{i t}$ is a residual error term. The firm-specific fixed effects capture whether a firm systematically overpays or underpays its workers relative to other firms. Recent evidence suggests that those firm effects explain a significant proportion of the variance of wages or earnings. Proportions vary between 15 and 25\% depending on the country. This means that $15 \%$ to $25 \%$ of wage or earnings differentials are the result of firm-specific time-invariant factors. This is consistent with the widely documented unobserved firmspecific productivity differences (Syverson (2011)).

$X_{i t}$ includes observed characteristics of the worker, the firm or the job, the impacts of which on income are captured by $\beta$. In our set of time-varying covariates, we include a quartic function of age, marital status, family status, province of residence, and year fixed effects.

Because worker fixed effect also captures the time-invariant cohort effect, the linear impact of age cannot be identified. This is because age is perfectly collinear with time-invariant year of birth and year. Instead, we normalize age at 46 and impose a linear restriction by dropping the linear term in the quartic function. This restriction effectively restricts the age profile to be flat at age 46, which is supported by the age-earnings profile in our data (see Dostie, Li, Card, and Parent (2020)).

As with the use of any administrative data, we have limited information on workers' characteristics such as education or ethnicity. However, because of the time-invariant nature of these characteristics, they are well captured by worker fixed effects. Similarly, firm fixed effects capture time-invariant characteristics such as industry. 
Any time-varying characteristics other than the observables mentioned above are included in the error term. This captures any measurement errors, labour market shocks, shocks to personal conditions (e.g., health), and job transitions.

Some articles have debated the appropriateness of a linear model with non-nested worker and firm effects. In particular, inference on parameters of the model is valid as long as:

$$
E[\epsilon \mid X, D, F]=0
$$

where $D$ and $F$ are the design matrices for worker and firm effects; i.e. worker and firm effects will be biased unless worker mobility is uncorrelated with the time-varying residual components of earnings. Dostie, Li, Card, and Parent (2020), who use the same data we do in this paper, provide a number of specification checks and find no indication that this assumption fails to hold in our data.

Comparisons of the firm fixed effects depend on observing a worker in two different firms. We refer to this set of workers and firms connected by movements of workers between firms as the connected set. The estimation is done using ordinary least squares regressions involving special routines to account for the high dimensionality of the problem. This model is estimated for men and women separately.

3.1. Firm effects normalization and the dual connected set. Because the equations for the determinants of earnings are estimated separately for men and women, and because our objective is to compare how firm effects contribute to earnings, it is necessary to find a way to compare firm effects estimated from the two separate models. This is because in each equation, the firm-specific earnings premium is identified only relative to a reference set of firms. To identify a reference set of firms, we estimate the following equations for men (M) and women (W):

$$
\begin{aligned}
& \hat{\psi}_{J(i, t}^{M}=\pi_{0}^{M}+\pi_{1}^{M} \max \left(0, S_{j(i, t)}^{0}\right)+\nu_{j(i, t)}^{M} \\
& \hat{\psi}_{J(i, t}^{W}=\pi_{0}^{W}+\pi_{1}^{W} \max \left(0, S_{j(i, t)}^{0}\right)+\nu_{j(i, t)}^{W}
\end{aligned}
$$

in which $S_{j(i, t)}^{0}$ is the average value-added per worker in firm $j$ and $\pi_{0}$ is typically interpreted as a threshold after which the firm begins to share rents (Card, Cardoso, and Kline (2016)). These equations assume that true firm effects are zero for low value-added firms and start rising after threshold $\pi_{0}$, meaning that firms start sharing surpluses with workers after this threshold is passed.

3.2. Decomposing the effect of firm-level pay premiums. By denoting the firm effects estimated from the AKM model for women by $\psi_{j(i, t)}^{W}$ and for men by $\psi_{j(i, t)}^{M}$, we 
can decompose the difference in the expected firm effect for women and men into a bargaining component and a sorting component. ${ }^{6}$ This yields

$$
\begin{array}{r}
E\left[\psi_{j(i, t)}^{M} \mid \text { Men }\right]-E\left[\psi_{j(i, t)}^{W} \mid \text { Women }\right]=E\left[\psi_{j(i, t)}^{M}-\psi_{j(i, t)}^{W} \mid \text { Men }\right] \\
+E\left[\psi_{j(i, t)}^{W} \mid \text { Men }\right]-E\left[\psi_{j(i, t)}^{W} \mid \text { Women }\right]
\end{array}
$$

The first term on the right-hand side

$$
E\left[\psi_{j(i, t)}^{M}-\psi_{j(i, t)}^{W} \mid M e n\right]
$$

is the bargaining effect as defined by Card, Cardoso, and Kline (2016). This effect measures the degree to which women obtain a smaller share of the surplus generated by the firms than their male counterparts. Using the terminology employed by Dostie, Li, Card, and Parent (2020), we refer to this component as the pay-setting effect in the description of the results.

The second term on the right-hand side of the equation

$$
E\left[\psi_{j(i, t)}^{W} \mid M e n\right]-E\left[\psi_{j(i, t)}^{W} \mid \text { Women }\right]
$$

is the sorting effect. The sorting component measures the extent to which women sort into different types of firms relative to men.

The sorting component captures the degree to which women are segregated between employers that pay differently, while the pay-setting component is thought to result from differences in how men and women are paid by the same employer. ${ }^{7}$ The degree to which these two factors impact gender earnings differentials will likely depend on labor market institutions such as the minimum wage or the importance of collective wage settings, as well as the degree of labour market fluidity.

The set of workers for which such a comparison can be made must work in firms that employ both men and women simultaneously. This set is called the dual-connected set. This selection rule effectively drops all firms that employ only women or only men. We discuss the impact of these selection rules in the next section.

\section{DATA}

4.1. Data source. This study uses data from of Statistics Canada's CEEDD between 2001 and 2015. The CEEDD is a linked database of workers and employers that covers

\footnotetext{
${ }^{6}$ Like most decompositions, results depend on the choice of the reference group. Our results, using men and women as the reference group -respectively- are very similar. As such, we present the former in this paper.

${ }^{7} \mathrm{~A}$ growing body of literature finds that employer segregation contributes more to the gender wage gap than occupational segregation (e.g. Jewell, Razzu, and Singleton (2020)).
} 
all individual and corporate tax filers. It can be accessed from Statistics Canada Business Data Access Centre (BDAC) in Ottawa.

Our target population is all workers, aged between 25 and 54 and employed by incorporated (T2) businesses in the business sector in Canada. ${ }^{8}$ For a given worker, income is measured using annual earnings from T2 employment. ${ }^{9}$ For a worker with multiple jobs (including self-employment) the highest paying job is considered only if his or her primary income is sourced from employment. Moreover, nominal annual earning is deflated by provincial Consumer Price Indexes (CPI, 2012=100). ${ }^{10}$ Lastly, as annual earnings confound gender difference in both pay and hours worked we focus on full-time equivalent workers only. The nature of work (full-time vs. part-time) is unavailable in the administrative data, so we apply a threshold of annual earnings of roughly $\$ 18,000$ derived from the 2012 minimum wage and full-time hours from the Labour Force Survey microdata file. ${ }^{11}$

For employers, labour productivity (used to capture firm characteristics) is measured using real value added per employee. ${ }^{12}$ Value added is measured as the sum of T4 payrolls and net income before taxes and extraordinary items and is reported in current dollars. Industry-specific deflators from the Canadian Productivity Program are used to deflate nominal values to real terms. Employment is measured by the average number of employees according to a given firm's payroll deductions and remittances (PD7) files. This accounts for possible seasonality and double counting as a result of multiple-job holders. Moreover, to allow for direct earnings comparisons by gender for a given employer, our sample includes incorporates businesses with a minimum of two

\footnotetext{
${ }^{8}$ The study includes all T2 businesses in the business sector only and excludes incorporated businesses operating in industries of education [North Ameircan Indutry Classification Code (61), health (62), and public administration (91).

${ }^{9}$ An individual may have multiple sources of income, i.e., from employment or self-employment. Employment income sums all Statements of Remuneration Paid (T4 slips) issued by incorporated businesses. Self-employment income sources include business, farming, fishing, rental, commissions, and professional income. We compare the two sources and only workers whose primary income was from employment are selected. Individuals with zero employment income are excluded, as were those with equal employment and self-employment income. The latter comprises of an extremely small proportion of all workers.

${ }^{10}$ The CPI is rebased to 2012 from 2002 as industry price deflators (which are used to deflate value added at the firm level) have a base year of 2012 .

${ }^{11}$ The monetary threshold of $\$ 18,733$ is calculated by multiplying the minimum wage of $\$ 10.07$ converted in 2012 constant dollars (Galarneau and Fecteau (2014)) by the average full-time working hours of 38.8 (Labour Force Survey, 2019) and a total of 48 weeks. This is equivalent to working full-time all year.

${ }^{12}$ Value added is the sum of capital costs, labour costs, and profits. Profits are the gross output net of total costs.
} 
employees throughout the sampled period. ${ }^{13}$ The identification of worker and firm fixed effects requires each worker to be observed over multiple years and multiple workers to be observed in each firm. Firms with very low output or value added below $\$ 100$ are excluded. Lastly, for firms that engage in multiple activities over the sampled period, their primary industry is used to define their dominant activities. ${ }^{14}$

Our final sample contains all prime-age full-time workers whose main job is with firms in the business sector that have two or more employees. It is worth noting that the exclusion of public sector and part-time employees likely results in a widening of the gender earnings gap for two reasons (also see the next subsection). First, the gender wage gap is narrower in the public sector; in 2015 the gender wage gap for workers aged 25 to 54 was between $7 \%$ and $10 \%$, compared with $14 \%$ for the economy as a whole. $^{15}$ Second, female part-time workers aged 25 to 54 accounted for an significant proportion of the female workforce - $19 \%$ in 2015 compared with $6 \%$ of their male counterparts. ${ }^{16}$ Female part-time workers also earn more than their male counterparts. In 2015 , the average wage rate for prime-age female workers was $\$ 21.21$ vs $\$ 20.72$ for male workers. ${ }^{17}$

4.2. Summary statistics. Table 1 summarizes mean annual earnings in 2015. Mean earnings on the main job for an individual who earns at least the minimum threshold are $\$ 72,600$ for men and $\$ 52,000$ for women, implying a gender earnings gap of $28 \%$. This gap is greater for older workers, workers who are married or in common-law, and for those with children. The gap has widened slightly over time (Figure 1). This widening gap contrasts with what has been observed in the workforce overall, which includes the public sector (where the gender earnings gap has been fairly stable since the 1990s) and part-time workers (where female workers earn more than their male counterparts). ${ }^{18}$ The pace at which the gap widens over the 15 -year period is fastest among younger workers, single workers (i.e., widowed, divorced, separated or never married) and those without children.

\footnotetext{
${ }^{13}$ The final sample includes all incorporated businesses in Canada that have employed at least two employees according to PD7 files. Incorporated businesses with fewer than two employees are excluded.

${ }^{14}$ Primary industry is defined as the mode of industry classification between 2001 and 2015.

${ }^{15}$ Labour Force Survey, Statistics Canada Table 14-10-0064-01.

${ }^{16}$ Labour Force Survey, Statistics Canada Table 14-10-0327-01.

${ }^{17}$ Labour Force Survey, Statistics Canada Table 14-10-0062-01. Full-time female workers earned less than their male counterparts; \$26.11 vs. \$29.86 in 2015 .

${ }^{18}$ Drolet (2002) finds that gender wage gap in Canada appears smaller within workplaces than the economy as a whole, which speaks to the low-wage nature of workplaces in which women work.
} 
Female workers represent about $35 \%$ of the workforce in our sample. Such representation varies by age, and marital and family status (Appendix Table A1 and Table A2.1). The degree to which female representation varies increases according to the characteristics of their employers, such as industry and firm age and size (Appendix Tables A2.2, A2.3 and A2.4), which suggests that firms play an important role in explaining earnings by gender.

Table 2 provides a descriptive overview of the characteristics of workers aged 25 to 54 who have earnings in at least one year in the CEEDD data from 2001 to 2015. The sample selection procedure may have dropped full-time workers who did not work the entire year, and - therefore - did not reach the income cut-off threshold. Because earnings can only be counted if they are received from a given employer in a year if they are above the "full-time equivalent" threshold, this procedure has two implications. First, workers experience a mechanical reduction in earnings in a given year if their main job ends part-way through the year. In contrast, workers starting a new job in the middle of the year experience a mechanical increase in earnings. Second, the selection procedure creates gap years for workers who are not employed for a substantial share of the year.

Columns 1 and 2 summarize the characteristics of male and female workers in our CEEDD sample. As described in the bottom row, there are approximately 40 million male workers and 22 million female workers in the sample. On average over the 15-year period, we have approximately 9 years of earnings data for each worker. This fraction of $9 / 15$ reflects the workers with earnings less than $\$ 18,000$ who are removed from our sample because of job changes or entry into the workforce or retirement part-way through the year.

Mean earnings on the main job for a worker who earns more than our minimum threshold are $\$ 66,000$ for men and $\$ 48,032$ for women, suggesting a 27\% earnings gap. The samples of male and female workers both have a mean age of 40 , with nearly $70 \%$ of workers in their $30 \mathrm{~s}$ and $40 \mathrm{~s}$. The provincial distribution of men and women are also similar; of approximately 24\% in Québec, $40 \%$ in Ontario, and $11 \%$ in British Columbia. Women tend to be employed at larger firms (308 employees vs. 199 for men) and tend to work at firms with a higher share of women (60\% vs. $30 \%$ for men) and immigrants (19\% vs. $16 \%$ for men) in their workforce.

The worker and firm fixed effects in the AKM style model are identified only in the connected set (Abowd, Creecy, and Kramarz (2002)). Columns 4 and 5 summarize the characteristics of men and women in the connected set of male and female workers, respectively. For men, the connected set includes $97 \%$ of all person-year observations, 
$84 \%$ of workers and $84 \%$ of firms. The exclusions correspond to firms wherein no employees worked at other firms in the connected set at some point between 2001 and 2015. Similarly, the connected set for women contains $96 \%$ of person-year observations, $81 \%$ of workers and $85 \%$ of firms. The characteristics of the connected sets are fairly similar to the full set used in columns 1 and 2 with one exception - the median firm size increases slightly for both connected sets to 207 and 323, respectively.

To compare firm effects between men and women, we turn to the dual-connected set. This step excludes firms with no connected male or female workers. Columns 5 and 6 summarize the workers' characteristics in the dual-connected set. The restriction to have at least one connected female worker has a more pronounced impact on firms in the connected set for male workers, eliminating 29\% (column 5) compared with $16 \%$ of the connected set of female workers (column 6). This implies that there are more firms in Canada with an all-male workforce than those with an all-female workforce.

The selection also has an impact on mean earnings and firm size. Mean earnings are higher in the dual connected set - by $3 \%$ for men and $1 \%$ women - and median firm size is substantially higher, at 310 for men (from 207 in the connected set, an increase of $48 \%$ ) and 424 for women (from 323 in the connected set, an increase of $30 \%$ ). The rest of the characteristics remain similar to those in the connected sets.

\section{Firms, And THE SORTING AND PAY-SETTING EFFECTS}

In this section, we first discuss briefly the coefficient estimates obtained from our linear model with worker and firm fixed effects - including a variance decomposition of earnings - and explain how firm fixed effects are normalized. We then turn to the decomposition results where we show the extent to which firms effects contribute to the gender earning gaps, and the role sorting and firm-specific pay-setting policies play in explaining this earnings gap.

5.1. Coefficient estimates: AKM model. The coefficient estimates from equation (3.1) are shown in Table 3. It is important to note that our model incorporates both worker and firm fixed effects, which are invariant over time. This modelling strategy allows us to implicitly take into account all fixed-over-time characteristics, such as education for a given worker or managerial quality within a firm. Moreover, our earnings models are estimated separately for male and female workers. Lastly, worker characteristics, including age, marital status, presence of children, and province of residence and year fixed effects are included in all regressions. 
In that context, coefficient estimates show gender differences with respect to the impact of many observable characteristics on earnings. For example, for male workers, all marital statuses other than married were associated with lower earnings, with the biggest difference being for widowed (-6.2\%) and single (-3.8\%) men. On average, divorced or separated men earn less than married men by $2.9 \%$ and $2.8 \%$ respectively. For female workers, nearly all marital statuses other than married are associated with higher earnings, with the biggest difference observed among single women, who earn $3.3 \%$ more than married women. Interestingly, there is a small earnings difference between divorced and separated women, the former earning 3.2\% more than married women and the latter earning just $2.0 \%$ more. One exception is widowed women who earn less than married women $(-1.6 \%)$. Because earnings are the dependent variable we use (effectively the product of hourly wages and hours of work per year), it is not possible to ascertain whether those differences are the result of differing wages or different work intensities.

Having children also has different impacts based on gender, but those effects are very small. We observe a small earnings penalty for both male and female workers. For male workers, the penalty is minimal $(-0.2 \%)$. For female workers, the penalty is larger $(-1.4 \%)$ when children were younger than 1 , and becomes marginally negative as children grow older.

5.2. AKM model: Analysis of variance. Table 4 presents the summary statistics from the previous regression. To better understand the role of firms in determining earnings, Table 4 also includes results from decomposing the variance of earnings. The most important contributor to total variance is person effects, explaining $58.1 \%$ of the variance of earnings for male workers and $68.5 \%$ of that for female workers. This lower contribution of person effects for male workers is compensated by a higher contribution of the variance of predicted earnings based on observable characteristics $(X \hat{\beta})$ and associated covariances, contributing to $11.2 \%$ of the variance for male workers compared with only $3.9 \%$ for female workers.

Firm fixed effects explain a residual of $11.1 \%$ and $11.3 \%$ for male and female workers respectively. Interestingly, the covariance between person and firm effects is positive $(3.5 \%)$ for male workers and zero for female workers. ${ }^{19}$ This positive covariance for

\footnotetext{
${ }^{19}$ This correlation is similar to the one found by Abowd, Lengermann, and McKinney (2003) who report a correlation of 0.08 for U.S. workers. A recent working paper by Bonhomme, Holzheu, Lamadon, Manresa, Mogsta, and Setzler (2020) claims that limited mobility bias tends to overstate the contribution of firms effects to the earnings dispersion. While previous research finds firms contributing 15 to $25 \%$ to earnings dispersion, these authors claim the bias-adjusted contribution is closer to $5 \%$ to $15 \%$. However, echoing Andrews, Gill, Schank, and Upward (2008)) these authors also find this
} 
male workers is indicative of some amount of positive assortative matching for them, a phenomenon by which high-wage male workers are more likely to be employed in highearnings firms; i.e., those with above-average earnings for unobserved reasons compared with their peers. The results show no evidence of positive assortative matching for female workers. This, in turn, suggests that differential sorting between genders is likely to explain part of the gender earnings gap.

\subsection{Normalizing the firm fixed effects: Hockey stick regression results. Be-} cause firm fixed effects are obtained from separate regressions for male and female workers, they need to be normalized to ensure meaningful comparisons between genders. Figure 2 plots firm fixed effects against real value added per worker in logarithms for male and female workers. The plot is relatively flat followed by an upswing - known in Canada as a hockey stick figure. Our strategy then relies on identifying the inflection point in Figure 2 and normalizing the firm fixed effects according to their average value for low value-added firms in the flat portion of the curve.

Table 5 shows the results from estimating equations (3.3) and (3.4) separately for male and female workers. The identified inflection point is similar for male and female workers. The slope of the curve after the inflection point is higher for men than for women (0.139 versus 0.108 ), indicating that male workers are able to capture a higher share of the surplus in high value-added firms. This, in turn, suggests that the impact of firm-specific pay policies will differ between genders. In our decomposition results below, we compute the exact contribution these policies make to the gender earnings gap.

\subsection{Decomposition results: Contribution of firm premiums, role of sorting} and pay-setting effects. Table 6 presents our main decomposition results. Different rows refer to various subgroups for which the decomposition is computed: age group, marital status, presence of children, and selected provinces. Column 1 shows the gender earnings gap, columns 2 and 3 show the average firm effects for male and female workers, and column 4 shows the total contribution of firm premiums to the gender earnings gap - the difference between columns 2 and 3.

bias to be less important in longer panels (see Bonhomme, Holzheu, Lamadon, Manresa, Mogsta, and Setzler (2020), Figure 9), such as the one we use in this paper covering a 15-year period. Moreover, Bonhomme, Holzheu, Lamadon, Manresa, Mogsta, and Setzler (2020) show that excluding relatively small firms helps attenuate this bias (Figure 11). Small firms with fewer than two employees and those with less than $\$ 100$ in real value added were excluded from the study sample. Future work is needed to assess whether the longer panel and the removal of very-small-sized firms are sufficient to produce unbiased estimates of the firms' contribution to the earnings gap in this data setting. 
The first row shows an average earnings gap of $26.8 \%$ (column 1) between male and female workers. With regard to the overall contribution of firm effects to the gender earnings gap, our results demonstrate that $22.8 \%$ (column 4 ) is attributable to the share of earnings specific to the firm. This estimate is in the ballpark of previously published estimates from a handful of countries for which wage data are available. This supports the notion that our sample selection criteria are effective in addressing the fact that our data record earnings only. As mentioned in Section 2, comparable estimates range from $8 \%$ in France (Coudin, Maillard, and Tô (2018)) to nearly 60\% in Brazil (Morchio and Moser (2019)). Our estimates for Canada are closest to those for Portugal (Card, Cardoso, and Kline (2016)) and 2000s West Germany (Bruns (2019)), at $20.9 \%$ and $25.9 \%$, respectively.

Columns 5 and 6 decompose column 4 into sorting and pay-setting effects. As is the case for most decomposition methods, the results can be sensitive to the choice of reference group, either male or female workers. We compute those using both reference groups and obtain very similar results. For demonstration purposes, we show only one set of results here. On average, the sorting and pay-setting effects explain respectively $47.7 \%$ and $52.3 \%$ of the firm contribution to the gender earnings gap. The effect of pay-setting is larger than what has been found in other countries. As discussed in Section 2, research on the mechanisms underlying the relative importance of sorting versus pay-setting channels remains in its early stages. In studies where the pay-setting channel was found to play a particularly limited role, authors have evoked minimum wage and centralized wage bargaining institutions to explain the observed pattern. Following this strand of literature, our results may partly stem from Canada's largely decentralized collective bargaining system (e.g., Card, Lemieux, and Riddell (2003); Drolet and Mumford (2012)). In Section 7 we show evidence that other mechanisms may also be at play for single workers and non-parents. ${ }^{20}$

\section{DiffEREnCES By AGE AND MARITAL STATUS}

Next, we turn to life-cycle patterns - variation by age group - and to differences by marital status.

\footnotetext{
${ }^{20}$ We cannot eliminate the possibility that our estimates are in part driven by the use of earnings rather than wages. As such, our estimate of the pay-setting effect might reflect both differences in wages and intensities of work between genders. However, we do not believe this is the main factor driving our results. First, other studies using earnings obtain lower estimates of the pay-setting effect (Casarico and Lattanzio (2019); Morchio and Moser (2019)). Second, Gallen, Lesner, and Vejlin (2019) decomposes both the wage gap and the hours gap - using data for Denmark - and finds that sorting contributes respectively 11 and $13 \%$ of the overall gap; if anything, sorting is slightly stronger for hours worked than for wages.
} 
6.1. Life-cycle patterns. The gender earnings gap increases with age, from $16.5 \%$ among individuals aged 25 to 29 , to $30.3 \%$ among those aged 50 to 54 . Conversely, the firm contribution to the gap drops from almost $30 \%$ between 25 and 29, to some $20 \%$ after age 30; that is, as workers age other mechanisms become relatively more important. Finally, as workers age the sorting effect explains a growing proportion of the total contribution of firm premiums to the gender earnings gap, and the pay-setting effect a correspondingly declining one. In absolute terms, the sorting effect increases with age whereas the pay-setting effect remains almost flat, around 3.2 percentage points. In other words, the odds for women to obtain a higher share of firm surplus do not improve as they age. These results confirm existing findings from other countries.

As discussed in Section 2, the growing importance of sorting over the life-cycle has been linked to the birth of children (Coudin, Maillard, and Tô (2018); Bruns (2019)). This is consistent with the large literature documenting the fact that women are more likely to trade off pay for other job features, such as flexible work arrangements and shorter commutes (e.g., Goldin (2014); Le Barbanchon, Rathelot, and Roulet (2020)). In line with this, we find that the gender earnings gap is larger among women with children - $35.1 \%$ compared with $23.9 \%$ among women without children - and that it is substantially more attributable to the sorting channel: $59.1 \%$ of the contribution of firm premiums to the gender earnings gap among workers with children operates through sorting, compared with $42.7 \%$ among workers without children. To some extent, our evidence also suggests that the gender earnings gap and the importance of sorting are increasing with the age of children. Indeed, both are smaller for parents with children younger than six.

6.2. Differences by marital status. So far, the literature's understanding of the forces underlying sorting and pay-setting effects has largely relied on cross-subgroup comparisons (e.g., parents vs. non-parents). A key contribution of our paper is to characterize these effects by marital status, which is made possible by our data. Before doing so, we note that there is substantial variation in the gender earnings gap by marital status. The gap among common-law workers is only two thirds the size of the gap among married workers (23.1\% vs. $34.2 \%)$, and it is lowest among single workers $(10.8 \%)$.

The role of firms differs substantially by marital status. The total contribution of firm premiums to the gender earnings gap is lowest for married workers (20.1\%) and highest for single workers (41.6\%). The disparities, however, do not solely arise from 
life-cycle patterns. As we restrict the sample of single workers to those younger than 30 , the role of firms drops to $37.4 \%$.

The relative importance of the sorting and pay-setting channels also varies considerably by marital status. For example, the share explained by sorting is $53.1 \%$ for married workers, 9.9 percentage points higher than the share for workers in commonlaw relationships, and 22.8 percentage points higher than for single workers. Similar to the results in Section 6.1, these differences are driven almost entirely by disparities in the sorting effect. It accounts for 1.4 to 4.2 percentage points of the gender earnings gap, compared with 3.1 to 3.3 percentage points for the pay-setting effect. Again, some of the differences between married and single workers may stem partly from life-cycle differences. However, the distinction between married and common-law workers suggests that family composition decisions - such as marital formation and dissolution - may be associated with differences in the ways in which firms impact the gender earnings gap, beyond mechanisms associated with the presence of children.

\section{INTERPROVINCIAL DIFFERENCES}

In this section we discuss interprovincial comparisons of the role of firms in the gender earnings gap, and of the relative importance of the sorting and pay-setting channels. Among other things, this allows us to ascertain whether the strength of the pay-setting effect is region-specific, or uniform across the country. Our results in Table 6 focus on the three largest provinces in Canada, Québec, Ontario and British Columbia, which account for approximately three quarters of the country's labour force.

Consistent with Baker and Drolet (2010) and Schirle (2015), our findings show that the earnings gap is highest in British Columbia (30.8\%) and lowest in Québec (21.0\%), with Ontario falling somewhere in between $(26.3 \%) .{ }^{21}$ The contribution of firms to the gap is very similar for Ontario and Québec (23.6\% and 25.6\%, respectively) and somewhat lower in British Columbia (19.2\%).

Of particular interest are the relative roles of sorting and pay-setting in the three provinces considered. In absolute terms, sorting contributes only 2.0 percentage points to the gender earnings gap in Québec, 2.9 in Ontario and 3.5 in British Columbia. Similarly, pay-setting accounts for 2.4 percentage points in British Columbia, well below the 3.3 in Ontario and 3.4 in Québec. As a result, the overall role of firms in the gender earnings gap in British Columbia is primarily driven by sorting, which accounts for $59.2 \%$ of the effect. This is similar to what has been documented for Europe and

\footnotetext{
${ }^{21}$ Using wage data Baker and Drolet (2010) find a greater similarity between the gaps in Québec and Ontario than we do using earnings data.
} 
South America. In comparison, the opposite is observed in Québec, where only one third of the firm effect stems from sorting (36.5\%). In Ontario, the relative roles of sorting and pay-setting are almost equal, at $46.5 \%$ and $53.5 \%$, respectively. ${ }^{22}$

The interprovincial differences in sorting and pay-setting highlight the importance of caution when using cross-country comparisons to draw conclusions on the role of institutions in this context. For instance, Québec is the province where pay-setting is most important, but it also has the highest union coverage. In 2015, 36.1\% of the Québec workforce was unionized, compared with an overall 28.6\% in Canada, 25.3\% in Ontario and $28.8 \%$ in British Columbia, respectively. Conversely, despite many cultural and institutional similarities across provinces, we find that there is substantial variation in the role of firms. In the next section, we discuss the role of sorting and pay-setting by parental and marital status, separately by province. This allows us to gain further insight into the interprovincial differences presented here, as well as to evaluate the robustness of earlier findings from Sections 6.1 and 6.2.

7.1. Life-cycle patterns across provinces. The life-cycle patterns discussed in Section 6.1 generally hold across provinces (see Table 7). As was the case for Canada as a whole, the gender pay gap is greater among people with children in the three provinces considered. However, that distinction is larger in Québec and Ontario than in British Columbia: in the former two provinces, the gap among workers with children is respectively $55.2 \%$ and $54.8 \%$ higher than the gap among workers without children (28.6 vs. $18.4 \%$ in Québec, and 35.4 vs. $22.9 \%$ in Ontario); whereas it is only $43.8 \%$ greater in British Columbia (40.1 vs. 27.9\%)

Furthermore, the greater importance of sorting among workers with children is particularly pronounced in Québec. In all three provinces, the absolute size of the paysetting effect is fairly similar across workers with and without children, whereas the size of the sorting effect differs substantially. In Québec however, the sorting effect among workers with children is more than twice as large as among people without children (3.3 vs. 1.5 percentage points, or $122.9 \%$ higher). In comparison, it is only 83.9\% and 63.5\% higher in Ontario and British Columbia, respectively. Another way to look at this is to note that interprovincial differences in sorting are much smaller among parents than among non-parents. This is interesting, given that much of the discussion around the importance of sorting in the literature has centered around the impact of births on female and male workers.

\footnotetext{
${ }^{22}$ These differences echo the findings from Schirle (2015), who estimates that differential sorting across industries and occupations explains approximately $42.5 \%$ of the gender wage gap in British Columbia in 2014, and only $31.0 \%$ of the gap in Québec and $30.5 \%$ in Ontario.
} 
7.2. Differences by marital status across provinces. As is the case for the lifecycle patterns, many of the differences by marital status are also observed across provinces (see Table 8). As such, the gender pay gap is largest for married workers than for those in common-law unions, and smallest for single workers. However, the distinction between married and common-law is smallest in Québec (6.2 percentage points) and largest in Ontario (12.9 percentage points). Looking at how the gaps for married and common-law workers compare to the gaps for workers in other living arrangements, it appears that the difference is driven by a higher gap for people in common-law unions in Québec. This is consistent with the limited legal standing of common-law partnerships in Québec, compared to what prevails in other provinces.

Next, whether we consider Canada as a whole or the provinces separately, we find that firms contribute a greater share of the gender pay gap among single workers, and that the firm effect among singles is largely attributable to pay-setting. Again, there is interprovincial variation in the magnitude of these differences. In particular, the sorting channel is almost non-existent among singles in Québec; it accounts for only 0.4 percentage points of the gender pay gap (or only $11 \%$ of firm effects). This is particularly striking when compared to the results in Table 7, for parents and non-parents in Québec. Indeed, although we do find sorting to be more modest among people without children, it nonetheless explains a non-negligible $30.2 \%$ of the contribution of firm premiums to their gender earnings gap. We interpret this as evidence that the difference between single and other individuals cannot be fully accounted for by differences associated with the presence of children.

\section{Conclusion}

It is well established that the gender earnings gap has reached a plateau in highincome countries, with little progress to speak of over the past three decades. Furthermore, research has unambiguously shown that breaking through this plateau will require a better understanding of the role firms play in the remaining gap. To this avail, a large and growing literature has studied differences in the types of firms that female and male workers are employed at, as well as gender disparities in the ability and willingness to access different positions within firms. In line with this, Card, Cardoso, and Kline (2016) and others after them have provided evidence suggesting that the former of the two channels plays a larger part in explaining firms' contribution to the gender earnings gap. However, much remains to be learned about the forces that underpin this observation. 
In this paper, we apply the methodology of Card, Cardoso, and Kline (2016) to the Canadian context. Using a large matched employer-employee data set, our sample covers all prime-age, full-time workers in the business sector between 2001 and 2015. We make three contributions to the literature on the relative importance of the sorting and pay-setting channels through which firms contribute to the gender earnings gap.

First, we show that if female workers benefited from the same firm premiums as male workers, the gender earnings gap in Canada would fall by $22.8 \%$. This is in the mid-range of what has been estimated for countries in Europe and South America, and constitutes the first estimate available for North America and for the Commonwealth more generally. Although the importance of the sorting effect in the overall gender earnings gap has been investigated in the United States (Sorkin (2017)) and the United Kingdom (Jewell, Razzu, and Singleton (2020)), their data do not allow for the decomposition of firm contributions into sorting and pay-setting effects. In the Canadian context, we find that the two channels account for near-equal shares of the firm contribution to the gender earnings gap. This contrasts with previous evidence, which has overwhelmingly found that pay-setting accounts for no more than $30 \%$ of the firm effect.

Second, we contribute to the literature that has used comparisons across subgroups to learn about the forces that may explain the relative importance of sorting and paysetting. Specifically, our data allows us to reproduce results separately by the marital status of workers. We find that sorting is most important for married workers, but muted among single workers. Furthermore, we find substantial differences between married workers and those in common-law unions, both in terms of the contribution of firms to the gender earnings gap and the role of sorting. We interpret this as evidence that life-cycle patterns alone cannot explain the substantial variation we observe in the role of firms across workers who differ in marital status. This is consistent with the large literature following the work of Chiappori (1988) and Chiappori (1992), which shows how intra-household dynamics impact workers' labour market outcomes. Our results suggest that bridging these two stands of literature might prove fruitful in furthering our understanding on how firms impact the gender earnings gap.

Finally, we document substantial variation across regions within Canada, with respect to the relative roles of sorting and pay-setting. We show that the importance of pay-setting is largely driven by Québec, and to a lesser extent by Ontario. This is of particular interest as Québec has historically featured greater centralization of wage pay-setting processes than the rest of Canada. As has been argued by Olivetti and Petrongolo (2017), understanding cross-country comparisons of the gender earnings 
gap requires assessing the overall portfolio of labour market and family policies that characterize different countries. Our results provide further evidence of the challenges involved in learning about institutions from these comparisons. Furthermore, we show that the importance of pay-setting in Québec is particularly pronounced among nonparents, and even more so among single workers. Until now research has mostly focused on increases in the importance of sorting that arise as families welcome children. Our results suggest that mechanisms involving single individuals and non-parents cannot be overlooked, as they can drive important differences within countries - and possibly across countries as well. 


\section{REFERENCES}

Abowd, J., R. H. Creecy, and F. Kramarz (2002). Computing person and firm effects using linked longitudinal employer-employee data. Longitudinal EmployerHousehold Dynamics Technical Papers.

Abowd, J., P. A. Lengermann, and K. McKinney (2003). The measurement of human capital in the U.S. economy. Longitudinal Employer-Household Dynamics Technical Papers.

Abowd, J. M., F. Kramarz, and D. N. Margolis (1999). High wage workers and high wage firms. Econometrica 67(2), 251-333.

Amuedo-Dorantes, C. and S. De la Rica (2006). The role of segregation and pay structure on the gender wage gap: Evidence from matched employer-employee data for Spain. The BE Journal of Economic Analysis \& Policy 5(1).

Andrews, M. J., L. Gill, T. Schank, and R. Upward (2008). High wage workers and low wage firms: negative assortative matching or limited mobility bias? Journal of the Royal Statistical Society: Series A (Statistics in Society) 171(3), 673-697.

Angelov, N., P. Johansson, and E. Lindahl (2016). Parenthood and the gender gap in pay. Journal of Labor Economics 34 (3), 545-579.

Baker, M., D. Benjamin, A. Desaulniers, and M. Grant (1995). The Distribution of the Male/Female Earnings Differential, 1970-1990. Canadian Journal of Economics 28(3), 479-501.

Baker, M. and M. Drolet (2010). A new view of the male/female pay gap. Canadian Public Policy / Analyse de Politiques 36(4), 429-464.

Barth, E., S. P. Kerr, and C. Olivetti (2017). The dynamics of gender earnings differentials: Evidence from establishment data. Technical report, National Bureau of Economic Research.

Bayard, K., J. Hellerstein, D. Neumark, and K. Troske (2003). New evidence on sex segregation and sex differences in wages from matched employee-employer data. Journal of labor Economics 21(4), 887-922.

Bertrand, M., S. E. Black, S. Jensen, and A. Lleras-Muney (2019). Breaking the glass ceiling? The effect of board quotas on female labour market outcomes in Norway. The Review of Economic Studies 86(1), 191-239.

Bertrand, M., C. Goldin, and L. F. Katz (2010). Dynamics of the gender gap for young professionals in the financial and corporate sectors. American Economic Journal: Applied Economics 2(3), 228-55. 
Blau, F. D. and L. M. Kahn (2017). The gender wage gap: Extent, trends, and explanations. Journal of Economic Literature 55(3), 789-865.

Bonhomme, S., K. Holzheu, T. Lamadon, E. Manresa, M. Mogsta, and B. Setzler (2020). How Much Should we Trust Estimates of Firm Effects and Worker Sorting? NBER Working Paper \#27368.

Boudarbat, B. and M. Connolly (2013). The gender wage gap among recent postsecondary graduates in Canada: A distributional approach. Canadian Journal of Economics 46(3), 1037-1065.

Bruns, B. (2019). Changes in workplace heterogeneity and how they widen the gender wage gap. American Economic Journal: Applied Economics 11(2), 74-113.

Card, D., A. R. Cardoso, and P. Kline (2016). Bargaining, Sorting, and the Gender Wage Gap: Quantifying the Impact of Firms on the Relative Pay of Women. The Quarterly Journal of Economics 131(2), 633-686.

Card, D., T. Lemieux, and W. C. Riddell (2003). Unions and the wage structure. International handbook of trade unions, 246-292.

Casarico, A. and S. Lattanzio (2019). What firms do: Gender inequality in linked employer-employee data. Cambridge Working Papers in Economics \#1966.

Chiappori, P.-A. (1988). Rational household labor supply. Econometrica, 63-90.

Chiappori, P.-A. (1992). Collective labor supply and welfare. Journal of Political Economy $100(3), 437-467$.

Chiappori, P.-A., B. Fortin, and G. Lacroix (2002). Marriage market, divorce legislation, and household labor supply. Journal of Political Economy 110(1), 37-72.

Cortés, P. and J. Pan (2019). When time binds: substitutes for household production, returns to working long hours, and the skilled gender wage gap. Journal of Labor Economics 37(2), 351-398.

Coudin, E., S. Maillard, and M. Tô (2018). Family, firms and the gender wage gap in France. IFS Working Papers \#W18/01.

Cruz, G. and T. Rau (2017). The effects of firm pay policies and equal pay laws on the gender wage gap in Chile. Working Paper.

Datta Gupta, N. and T. Eriksson (2012). HRM practices and the within-firm gender wage gap. British Journal of Industrial Relations 50(3), 554-580.

Del Bono, E. and D. Vuri (2011). Job mobility and the gender wage gap in Italy. Labour Economics 18(1), 130-142.

Dostie, B., J. Li, D. Card, and D. Parent (2020). Employer Policies and the Immigrant-Native Earnings Gap. NBER Working Paper \#27096. 
Drolet, M. (2002). Can the workplace explain Canadian gender pay differentials? Canadian Public Policy 28, S41-S63.

Drolet, M. (2011). Why has the gender wage gap narrowed? Perspectives on Labour and Income 11 (12), 3-13.

Drolet, M. and K. Mumford (2012). The gender pay gap for private-sector employees in Canada and Britain. British Journal of Industrial Relations 50(3), 529-553.

Galarneau, D. and E. Fecteau (2014). The ups and downs of minimum wage. Insights on Canadian Society (Statistics Canada Catalogue no. 75-006-X).

Gallen, Y., R. V. Lesner, and R. Vejlin (2019). The labor market gender gap in Denmark: Sorting out the past 30 years. Labour Economics 56, 58-67.

Goldin, C. (2014). A grand gender convergence: Its last chapter. American Economic Review 104(4), 1091-1119.

Goldin, C. and L. F. Katz (2016). A most egalitarian profession: pharmacy and the evolution of a family-friendly occupation. Journal of Labor Economics 34 (3), $705-746$.

Goussé, M. and M. Leturcq (2018). More or less unmarried. the impact of legal settings of cohabitation on labor market outcomes. CRREP working paper series 2018-08.

Gupta, N. D. and D. S. Rothstein (2005). The impact of worker and establishmentlevel characteristics on male-female wage differentials: Evidence from Danish matched employee-employer data. Labour 19(1), 1-34.

Heinze, A. and E. Wolf (2010). The intra-firm gender wage gap: A new view on wage differentials based on linked employer-employee data. Journal of Population Economics 23(3), 851-879.

Hensvik, L. E. (2014). Manager impartiality: Worker-firm matching and the gender wage gap. ILR Review 67(2), 395-421.

Javdani, M. (2015). Glass ceilings or glass doors? The role of firms in male-female wage disparities. Canadian Journal of Economics 48(2), 529-560.

Jewell, S. L., G. Razzu, and C. Singleton (2020). Who works for whom and the UK gender pay gap. British Journal of Industrial Relations 58(1), 50-81.

Kassenboehmer, S. C. and M. G. Sinning (2014). Distributional changes in the gender wage gap. ILR Review 6r(2), 335-361.

Kleven, H., C. Landais, J. Posch, A. Steinhauer, and J. Zweimüller (2021). Child penalties across countries: Evidence and explanations. NBER Working Paper (25524). 
Kunze, A. (2018). The gender wage gap in developed countries. The Oxford Handbook of Women and the Economy, 369.

Le Barbanchon, T., R. Rathelot, and A. Roulet (2020). Gender differences in job search: Trading off commute against wage. CEPR Discussion Paper No. DP15181.

Li, J., B. Dostie, and G. Duplain-Simard. What is the role of firm-specific pay policies on the gender earnings gap in Canada? Statistics Canada Analytical Studies Branch Research Paper Series. Catalogue no. 11F0019M - No. 456.

Masso, J., J. Meriküll, and P. Vahter (2020). The role of firms in the gender wage gap. University of Tartu - Faculty of Economics and Business Administration Working Paper Series 120.

Meyersson Milgrom, E. M., T. Petersen, and V. Snartland (2001). Equal pay for equal work? Evidence from Sweden and a comparison with Norway and the US. Scandinavian Journal of Economics 103(4), 559-583.

Morchio, I. and C. Moser (2019). The gender gap: Micro sources and macro consequences. In 2020 Meeting Papers, Volume 143. Society for Economic Dynamics.

Morissette, R. Picot, W. and Y. Lu (2013). The evolution of Canadian wages over the last three decades. Analytical Studies Branch Research Paper Series. Statistics Canada. Catalogue no. 11F0019M - No. 34.

Olivetti, C. and B. Petrongolo (2016). The evolution of gender gaps in industrialized countries. Annual review of Economics 8, 405-434.

Olivetti, C. and B. Petrongolo (2017). The economic consequences of family policies: lessons from a century of legislation in high-income countries. Journal of Economic Perspectives 31 (1), 205-30.

Pelletier, R. Patterson, M. and M. Moyser (2019). The gender wage gap in Canada: 1998 to 2018. Labour Statistics: Research Papers. Statistics Canada Catalogue no. $75-004-X$.

Pendakur, K. and S. Woodcock (2010). Glass ceilings or glass doors? Wage disparity within and between firms. Journal of Business $\&$ Economic Statistics 28(1), 181189.

Schirle, T. (2015). The gender wage gap in the Canadian provinces, 1997-2014. Canadian Public Policy 41(4), 309-319.

Sin, I., S. Stillman, and R. Fabling (2017). What drives the gender wage gap? Examining the roles of sorting, productivity differences, and discrimination. Motu Working Paper 17-15, Motu Economic and Public Policy Research (August 2017). 
Sorkin, I. (2017). The role of firms in gender earnings inequality: Evidence from the United States. American Economic Review 107(5), 384-87.

Stevenson, B. (2007). The impact of divorce laws on marriage-specific capital. Journal of Labor Economics 25(1), 75-94.

Syverson, C. (2011). What determines productivity? Journal of Economic Literature $49(2), 326-65$.

Voena, A. (2015). Yours, mine, and ours: Do divorce laws affect the intertemporal behavior of married couples? American Economic Review 105(8), 2295-2332.

Wiswall, M. and B. Zafar (2018). Preference for the workplace, investment in human capital, and gender. The Quarterly Journal of Economics 133(1), 457-507. 
9. TABles 
Table 1: Mean annual earnings in 2015

\begin{tabular}{lccc}
\hline & $\begin{array}{c}\text { Male } \\
\text { workers } \\
(1)\end{array}$ & $\begin{array}{c}\text { Female } \\
\text { workers } \\
(2)\end{array}$ & $\begin{array}{c}\text { Gender } \\
\text { earnings } \\
\text { gap } \\
(3)\end{array}$ \\
\hline Total & 72,556 & 52,001 & 0.72 \\
& & & \\
By age group & & & \\
25 to 29 & 50,664 & 40,020 & 0.79 \\
30 to 39 & 66,506 & 49,264 & 0.74 \\
40 to 49 & 82,470 & 57,215 & 0.69 \\
50 to 54 & 85,400 & 56,597 & 0.66 \\
& & & \\
By marital status & & & \\
Union & 80,507 & 54,288 & 0.67 \\
Alone & 57,421 & 48,273 & 0.84 \\
& & & \\
By family status & & & \\
$\quad$ Without children & 70,721 & 51,923 & 0.73 \\
With children & 85,539 & 52,334 & 0.61 \\
\hline
\end{tabular}

Notes: Authors' tabulation of the Canadian Employer-

Employee Dynamics Database (CEEDD), 2001-2015. Annual

earnings are set to missing if they are less than the rough threshold of $\$ 18,000$ threshold (in 2012 real dollars) - see text. Columns (1) and (2) show mean earnings by male and female workers, respectively. Column (3) shows the female-tomale earnings ratio by dividing column (2) by (1). Marital status is categorized into union (married or common law) and alone (separated, widowed, divorced or single). The children indicator divides workers into those with children and those without. 
Table 2: Descriptive statistics: Employees in selected samples from the CEEDD, 2001-2015

\begin{tabular}{|c|c|c|c|c|c|c|}
\hline & $(1)$ & $(2)$ & (3) & $(4)$ & (5) & (6) \\
\hline & \multirow{2}{*}{\multicolumn{2}{|c|}{ Overall Analysis Sample }} & \multicolumn{4}{|c|}{ Connected Sets of Workers } \\
\hline & & & \multicolumn{2}{|c|}{ All } & \multicolumn{2}{|c|}{ Dual connected set } \\
\hline & Male & Female & Male & Female & Male & Female \\
\hline Mean Age & 40.0 & 40.3 & 40.1 & 40.5 & 40.2 & 40.5 \\
\hline Fraction of age at $25-29(\%)$ & 14.0 & 13.7 & 13.5 & 12.9 & 13.3 & 12.9 \\
\hline Fraction of age at $30-39(\%)$ & 32.9 & 31.1 & 33.0 & 31.3 & 32.9 & 31.4 \\
\hline Fraction of age at $40-49(\%)$ & 36.4 & 38.0 & 36.9 & 38.7 & 37.0 & 38.7 \\
\hline Fraction of age at $50-54(\%)$ & 16.7 & 17.1 & 16.6 & 17.2 & 16.7 & 17.0 \\
\hline Mean earnings & 66,056 & 48,032 & 66,891 & 48,694 & 68,704 & 49,220 \\
\hline Fraction in Québec (\%) & 24.1 & 23.3 & 24.4 & 23.4 & 24.1 & 23.4 \\
\hline Fraction in Ontario $(\%)$ & 38.9 & 42.6 & 39.2 & 42.8 & 39.8 & 43.2 \\
\hline Fraction in British Columbia (\%) & 11.4 & 11.9 & 11.4 & 11.8 & 11.2 & 11.6 \\
\hline Median firm size & 199 & 308 & 207 & 323 & 307 & 419 \\
\hline Fraction of men (\%) & 71.3 & 48.2 & 71.2 & 48.3 & 69.8 & 50.1 \\
\hline Fraction of immigrants (\%) & 16.0 & 18.8 & 15.9 & 18.7 & 16.2 & 18.9 \\
\hline Mean log(value added/PD7) & 11.3 & 11.2 & 10.8 & 10.6 & 11.3 & 11.2 \\
\hline Number of person-year observations & $40,853,476$ & $21,564,688$ & $39,572,671$ & $20,738,690$ & $35,979,209$ & $19,640,363$ \\
\hline Number of persons & $6,603,544$ & $4,018,592$ & $5,558,251$ & $3,243,861$ & $5,341,050$ & $3,137,873$ \\
\hline Number of firms & 484,751 & 421,625 & 423,876 & 356,756 & 299,973 & 299,973 \\
\hline
\end{tabular}

Notes: Authors' tabulation of the Canadian Employer-Employee Dynamics Database, 2001-2015. PD7 employment is the average number of employees at a firm, calculated from the mean of all non-zero monthly employment submissions from payroll deductions and remittances (PD7). Annual earnings are set to missing if they are less than the rough threshold of $\$ 18,000$ (in 2012 real dollars); see text. Labour productivity is the value added per PD7 employment. 
Table 3: Summary of AKM estimation results

\begin{tabular}{|c|c|c|}
\hline & $\begin{array}{l}\text { Male workers } \\
\text { (1) }\end{array}$ & $\begin{array}{c}\text { Female workers } \\
(2)\end{array}$ \\
\hline Quadratic normalized age / 100 & $\begin{array}{c}-103.026^{* * *} \\
(0.467)\end{array}$ & $\begin{array}{c}-109.738^{* * *} \\
(0.587)\end{array}$ \\
\hline Cubic normalized age / 1,000 & $\begin{array}{l}988.075^{* * *} \\
(32.321)\end{array}$ & $\begin{array}{c}-1195.573^{\star \star \star} \\
(40.774)\end{array}$ \\
\hline Quartic normalized age / 10,000 & $\begin{array}{c}-1152.255^{* * *} \\
(56.387)\end{array}$ & $\begin{array}{c}-1778.428^{* * *} \\
(72.005)\end{array}$ \\
\hline Married (baseline: omitted) & & \\
\hline Common law & $\begin{array}{l}-0.021^{* * *} \\
(0.000)\end{array}$ & $\begin{array}{l}0.006^{* * *} \\
(0.000)\end{array}$ \\
\hline Widowed & $\begin{array}{l}-0.062^{* * *} \\
(0.001)\end{array}$ & $\begin{array}{l}-0.016^{\star \star *} \\
(0.001)\end{array}$ \\
\hline Divorced & $\begin{array}{l}-0.029^{* * *} \\
(0.000)\end{array}$ & $\begin{array}{l}0.032^{* * *} \\
(0.000)\end{array}$ \\
\hline Separated & $\begin{array}{l}-0.028^{* * *} \\
(0.000)\end{array}$ & $\begin{array}{l}0.020^{\star * *} \\
(0.000)\end{array}$ \\
\hline Single & $\begin{array}{l}-0.038^{* * *} \\
(0.000)\end{array}$ & $\begin{array}{l}0.033^{* * *} \\
(0.000)\end{array}$ \\
\hline Children indicator & $\begin{array}{l}-0.002^{\star \star \star} \\
(0.000)\end{array}$ & $\begin{array}{l}-0.001^{\star \star *} \\
(0.000)\end{array}$ \\
\hline Share of children aged younger than 1 & $\begin{array}{c}0.000 \\
(0.001)\end{array}$ & $\begin{array}{l}-0.013^{* * *} \\
(0.001)\end{array}$ \\
\hline Share of children aged 1 to 5 & $\begin{array}{l}0.002^{* * *} \\
(0.000)\end{array}$ & $\begin{array}{c}0.000 \\
(0.001) \\
\end{array}$ \\
\hline Year fixed effects & Yes & Yes \\
\hline Province fixed effects & $\begin{array}{l}\text { Yes } \\
39600.000\end{array}$ & $\begin{array}{c}\text { Yes } \\
20.700 .000\end{array}$ \\
\hline $\mathrm{R} 2$ & 0.838 & 0.836 \\
\hline R2 within & 0.319 & 0.330 \\
\hline
\end{tabular}

Note: This table presents a summary of the estimated two-way fixed effects model. The model is estimated for male (Column1) and female workers (Column 2) separately. Standard errors are in parentheses. ${ }^{* *}$ indicates $p<$ 0.01 . 
Table 4: Summary of the estimated two-way fixed effects model for male and female workers

\begin{tabular}{lcc}
\hline & Male workers & Female workers \\
& $(1)$ & $(2)$ \\
\hline Standard deviation of In-earnings & 0.5752 & 0.499 \\
Number of person-year observations & $39,572,671$ & $20,738,690$ \\
& & \\
Summary of parameter estimates & & \\
Number of person effects & $5,558,251$ & $3,243,861$ \\
Number of firm effects & 423,876 & 356,756 \\
Std. dev. of person effects (across person-yr obs.) & 0.438 & 0.413 \\
Std. dev. of firm effects (across person-yr obs.) & 0.192 & 0.167 \\
Std. dev. of Xb (across person-yr obs.) & 0.229 & 0.220 \\
Correlation of person-firm effects & 0.068 & 0.000 \\
RMSE of model & 0.251 & 0.222 \\
Adjusted R-squared of model & 0.810 & 0.803 \\
Correlation of estimated male-female firm effects ${ }^{\text {a/ }}$ & & 0.599 \\
(n) & & \\
Inequality decomposition of two-way fixed effects model: & & \\
Share of variance of In-earnings attributable to: & & \\
Person effects & & \\
Firm effects & 58.1 & 11.3 \\
Covariance of person and firm effects & 3.5 & 16.4 \\
XB and associated covariances & 11.2 & \\
Residual & 16.2 & \\
\hline
\end{tabular}

Note: Table presents summary of estimated two-way fixed effects model from Table 3. Model is estimated for male (column1) and female workers (column 2).

a/The correlation of estimated firm effects for male and female workers across all firms in the dual connected set 
Table 5: Regression of estimated firm effects on mean logged value added per worker

\begin{tabular}{lcc}
\hline & Male workers & Female workers \\
& $(1)$ & $(2)$ \\
\hline Breakpoint & $10.076^{* * *}$ & $10.055^{* * *}$ \\
& $(0.001)$ & $(0.001)$ \\
Slope coefficient & $0.138^{* * *}$ & $0.108^{* * *}$ \\
& $(0.000)$ & $(0.000)$ \\
Constant & $-0.162^{* * *}$ & $-0.109 * * *$ \\
& $(0.000)$ & $(0.000)$ \\
$\mathrm{N}$ & $55,700,000$ & $55,700,000$ \\
$\mathrm{R} 2$ & 0.289 & 0.199 \\
\hline
\end{tabular}

Note: Table displays coefficient estimates for the nonlinear regression of unnormalized estimated firm effects for firms in the dual-connected set. Standard errors are in parentheses. $* * *$ indicates $p<0.01$ 
Table 6: Contribution of firm-specific pay premiums to the gender earnings gap at dual connected firms

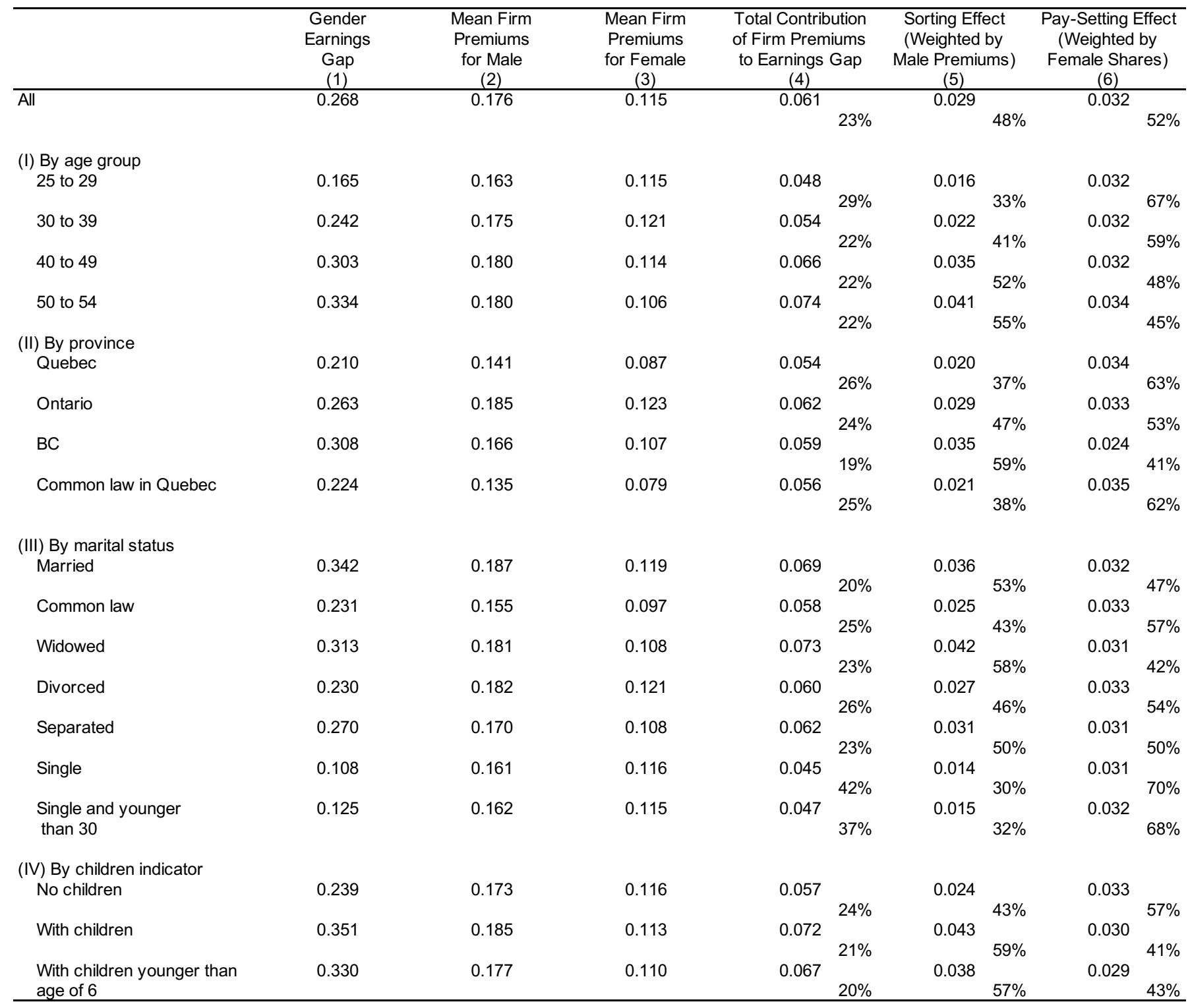

Note: Column (1) shows the mean log earnings gap between male and female workers in the dual connected set. Columns (2) and (3) show the mean (normalized) pay premiums received by male and female workers. Column (4) is the difference between columns (2) and (3) and measures the total contribution of firm-specific hiring and wage setting policies to the female earnings gap. Columns (5) and (6) decompose the total in column (4) into a between-firm sorting effect - column (5) - and a differential pay-setting effect - column (6). See text. Entries in parentheses are shares of overall gap explained by component in column. 
Table 7: Contribution of firm-specific pay premiums to the gender earnings gap at dual connected firms by province and family status

\begin{tabular}{|c|c|c|c|c|c|c|}
\hline & $\begin{array}{c}\text { Gender } \\
\text { Earnings } \\
\text { Gap } \\
\text { (1) }\end{array}$ & $\begin{array}{l}\text { Mean Firm } \\
\text { Premiums } \\
\text { for Male } \\
\text { (2) }\end{array}$ & $\begin{array}{l}\text { Mean Firm } \\
\text { Premiums } \\
\text { for Female } \\
\text { (3) }\end{array}$ & $\begin{array}{l}\text { Total Contribution } \\
\text { of Firms Premium } \\
\text { to Earnings Gap } \\
\text { (4) }\end{array}$ & $\begin{array}{c}\text { Sorting Effect } \\
\text { (Weighted bty } \\
\text { Male Premiums) } \\
\text { (5) }\end{array}$ & $\begin{array}{l}\text { Pay-Setting Effect } \\
\text { (Weighted by } \\
\text { Female Shares) } \\
\text { (6) }\end{array}$ \\
\hline \multicolumn{7}{|l|}{ Canada } \\
\hline \multirow[t]{2}{*}{ All } & 0.268 & 0.176 & 0.115 & 0.061 & 0.029 & 0.032 \\
\hline & & & & $23 \%$ & $48 \%$ & $52 \%$ \\
\hline \multirow[t]{2}{*}{ No children } & 0.239 & 0.173 & 0.116 & 0.057 & 0.024 & 0.033 \\
\hline & & & & $24 \%$ & $43 \%$ & $57 \%$ \\
\hline \multirow[t]{2}{*}{ With children } & 0.351 & 0.185 & 0.113 & 0.072 & 0.043 & 0.03 \\
\hline & & & & $21 \%$ & $59 \%$ & $41 \%$ \\
\hline \multicolumn{7}{|l|}{ Québec } \\
\hline \multirow[t]{2}{*}{ All } & 0.210 & 0.141 & 0.087 & 0.054 & 0.020 & 0.034 \\
\hline & & & & $26 \%$ & $37 \%$ & $63 \%$ \\
\hline \multirow[t]{2}{*}{ No children } & 0.184 & 0.138 & 0.088 & 0.050 & 0.015 & 0.035 \\
\hline & & & & $27 \%$ & $30 \%$ & $70 \%$ \\
\hline \multirow[t]{2}{*}{ With children } & 0.286 & 0.151 & 0.085 & 0.066 & 0.033 & 0.033 \\
\hline & & & & $23 \%$ & $50 \%$ & $50 \%$ \\
\hline \multicolumn{7}{|l|}{ Ontario } \\
\hline \multirow[t]{2}{*}{ All } & 0.263 & 0.185 & 0.123 & 0.062 & 0.029 & 0.033 \\
\hline & & & & $24 \%$ & $47 \%$ & $53 \%$ \\
\hline \multirow[t]{2}{*}{ No children } & 0.229 & 0.181 & 0.123 & 0.058 & 0.024 & 0.034 \\
\hline & & & & $25 \%$ & $41 \%$ & $59 \%$ \\
\hline \multirow[t]{2}{*}{ With children } & 0.354 & 0.199 & 0.125 & 0.074 & 0.044 & 0.030 \\
\hline & & & & $21 \%$ & $59 \%$ & $41 \%$ \\
\hline \multicolumn{7}{|l|}{ BC } \\
\hline \multirow[t]{2}{*}{ All } & 0.308 & 0.166 & 0.107 & 0.059 & 0.035 & 0.024 \\
\hline & & & & $19 \%$ & $59 \%$ & $41 \%$ \\
\hline \multirow[t]{2}{*}{ No children } & 0.279 & 0.164 & 0.108 & 0.055 & 0.031 & 0.025 \\
\hline & & & & $20 \%$ & $55 \%$ & $45 \%$ \\
\hline \multirow[t]{2}{*}{ With children } & 0.401 & 0.175 & 0.103 & 0.073 & 0.050 & 0.023 \\
\hline & & & & $18 \%$ & $69 \%$ & $31 \%$ \\
\hline
\end{tabular}

Note: Column (1) shows the mean log earnings gap between male and female workers in the dual connected set. Columns (2) and (3) show the mean (normalized) pay premiums received by male and female workers. Column (4) is the difference between columns (2) and (3) and measures the total contribution of firm-specific hiring and wage setting policies to the female earnings gap. Columns (5) and (6) decompose the total in column (4) into a between-firm sorting effect - column (5) - and a differential pav-settina effect - column (6). See text. Entries in parentheses are shares of overall aap explained bv component in 
Table 8 Contribution of firm-specific pay premiums to the gender earnings gap at dual connected firms (marital status per province)

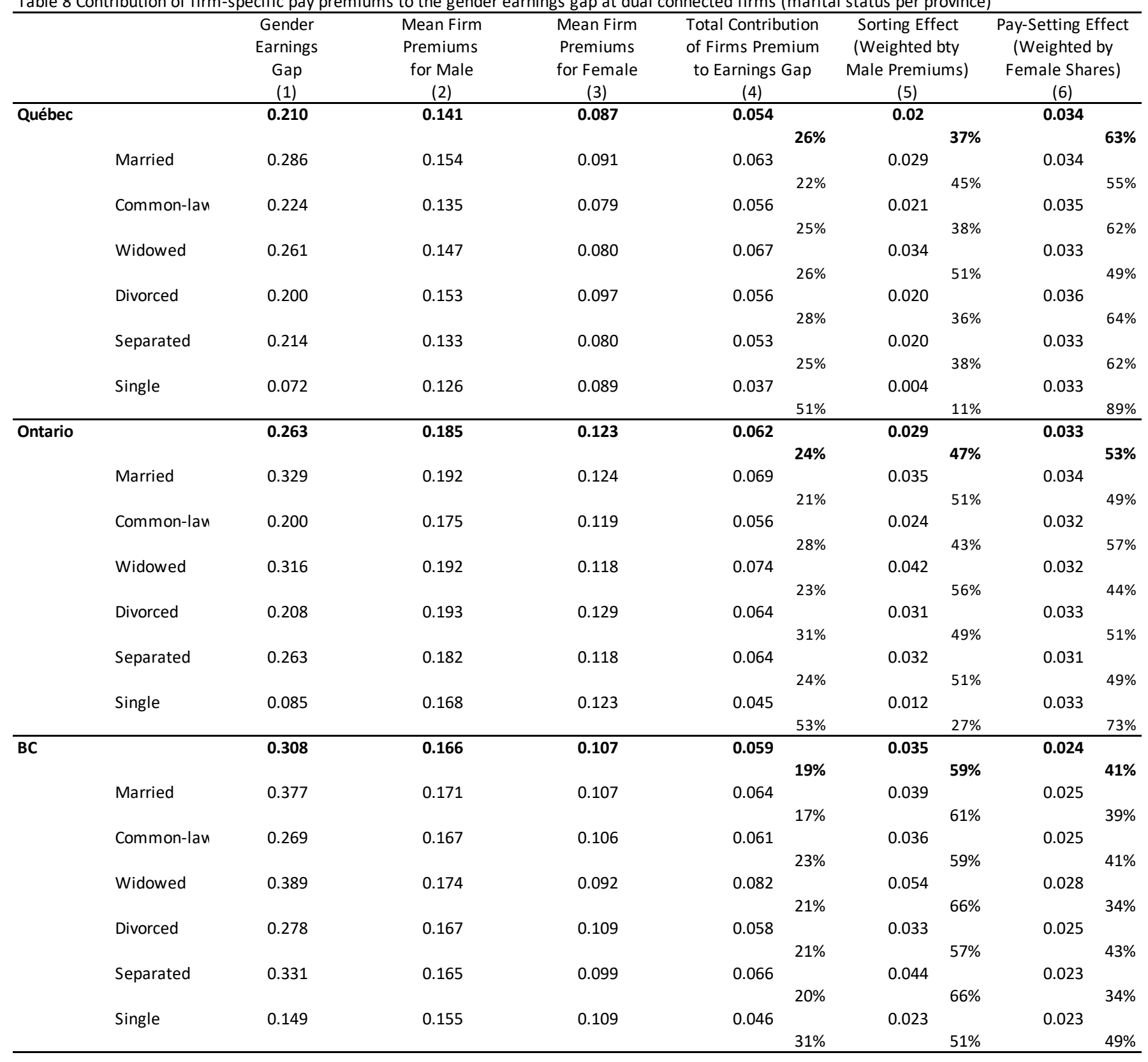

Note: Column (1) shows the mean log earnings gap between male and female workers in the dual connected set. Columns (2) and (3) show the mean (normalized) pay premiums received by male and female workers. Column (4) is the difference between columns (2) and (3) and measures the total contribution of firm-specific hiring and wage setting policies to the female earnings gap. Columns (5) and (6) decompose the total in column (4) into a between-firm sorting effect - column (5) - and a differential pay-setting effect - column (6). See text. Entries in parentheses are shares of overall gap explained by component in column. 
10. Figures 
Figure 1: Mean gender earnings gap, 2001-2015
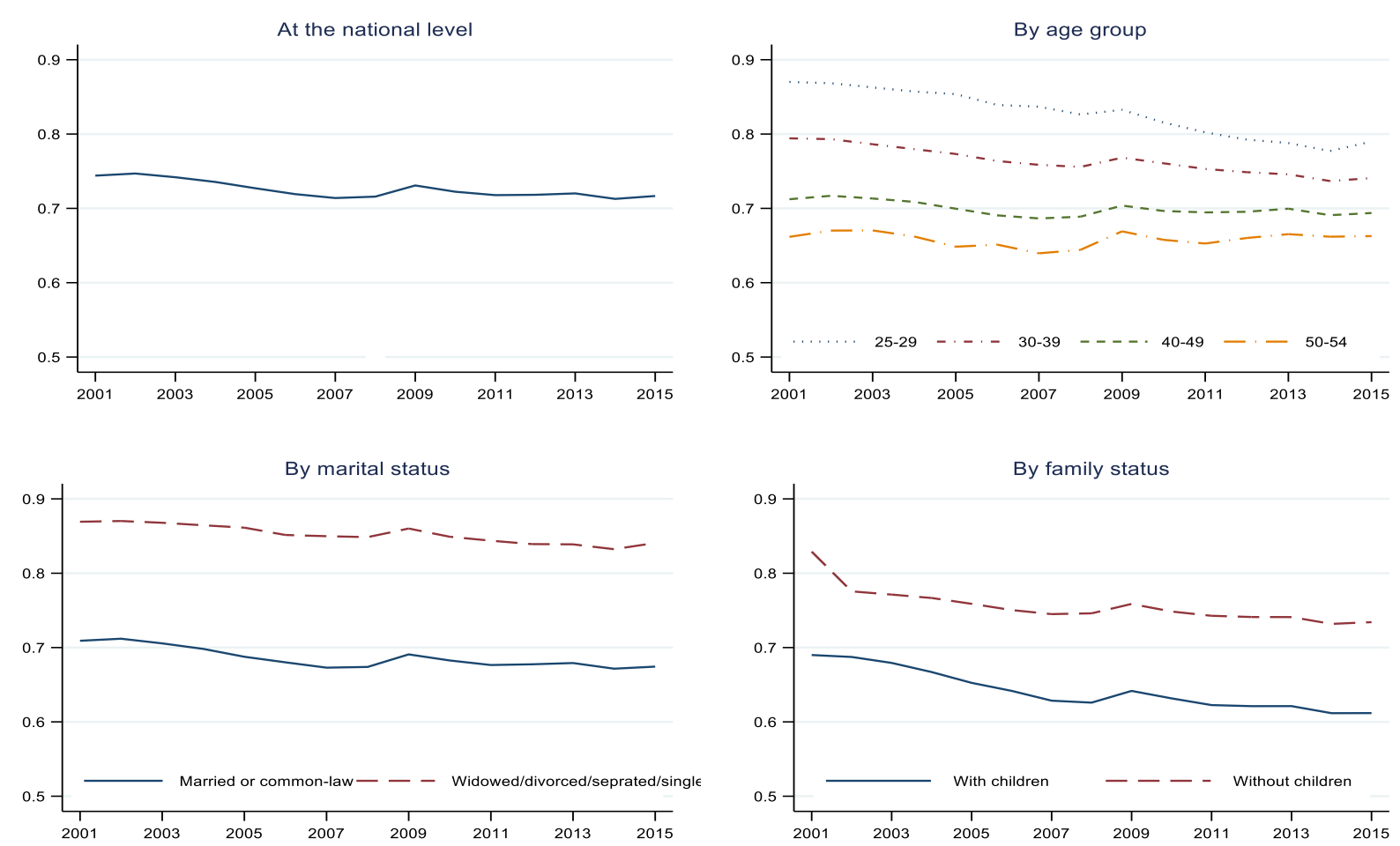

Note: Our sample includes all prime-age full-time workers whose main job is with a firm in the business sector with two or more employees. Annual earnings are set to missing if they are less than the rough threshold of $\$ 18,000$ (in 2012 real dollars); see text. Marital status is categorized into union (married or common-law) and alone (separated, widowed, divorced or single). The children indicator divides workers into those with children and those without.

Source: Authors' tabulation of the Canadian Employer-Employee Dynamics Database, 2001-2015. 
Figure 2: Firm effects and labour productivity, 2001-2015
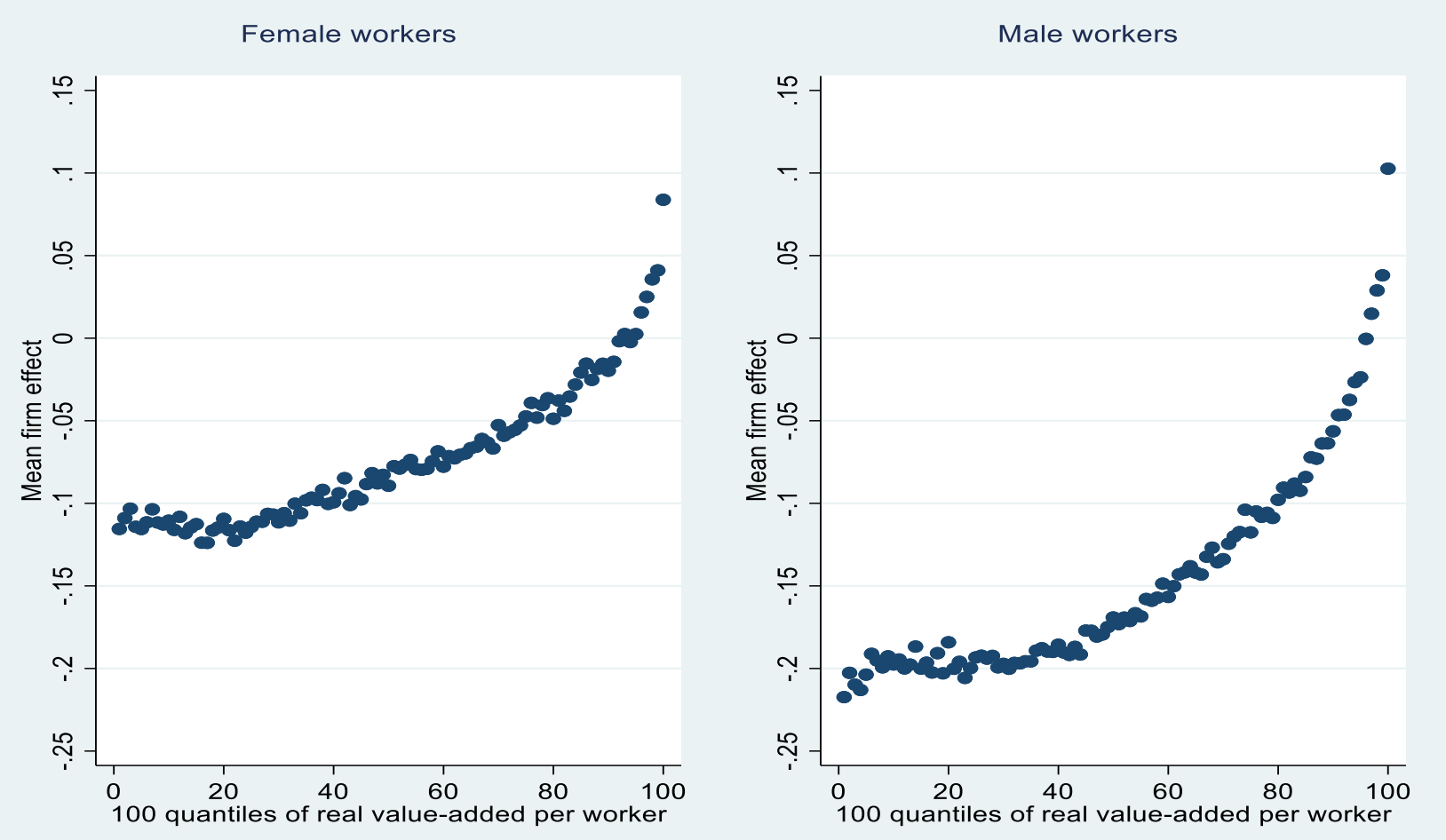

Note: The figure plots the firm effect and logarithmic firm labour productivity (real value added per worker) in 100 quantiles from Table Source: Authors' tabulation of the Canadian Employer-Employee Dynamics Database, 2001-2015. 
Appendix A. Appendix Tables 
Appendix Table A1: Mean gender composition by age group, marital status, and children indicator, 2001-2015 (Percent)

\begin{tabular}{lcc}
\hline & $\begin{array}{c}\text { Male } \\
\text { Workers }\end{array}$ & $\begin{array}{c}\text { Female } \\
\text { Workers }\end{array}$ \\
\hline Age group & & \\
25 to 29 & 65.9 & 34.1 \\
30 to 39 & 66.6 & 33.4 \\
40 to 49 & 64.5 & 35.5 \\
50 to 54 & 64.8 & 35.2 \\
Marital Status & & \\
$\quad$ Union & 67.2 & 32.8 \\
$\quad$ Alone & 62.0 & 38.0 \\
Family Status & & \\
$\quad$ Without children & 67.0 & 33.0 \\
$\quad$ With children & 60.7 & 39.3 \\
$\quad$ Total & 65.5 & 34.5 \\
\hline
\end{tabular}

Note: Authors' tabulation of the Canadian EmployerEmployee Dynamics Database, 2001-2015. Annual earnings are set to missing if less than roughly $\$ 18,000$ threshold (in 2012 real dollars) -- see text. Marital status is categorized into union (married and common-law) and alone (separated / widowed / divorced and single). Children indicator divides workers into those with children and those without. 
Appendix Table A2.1: Mean gender composition by province, 2001-2015 (Percent)

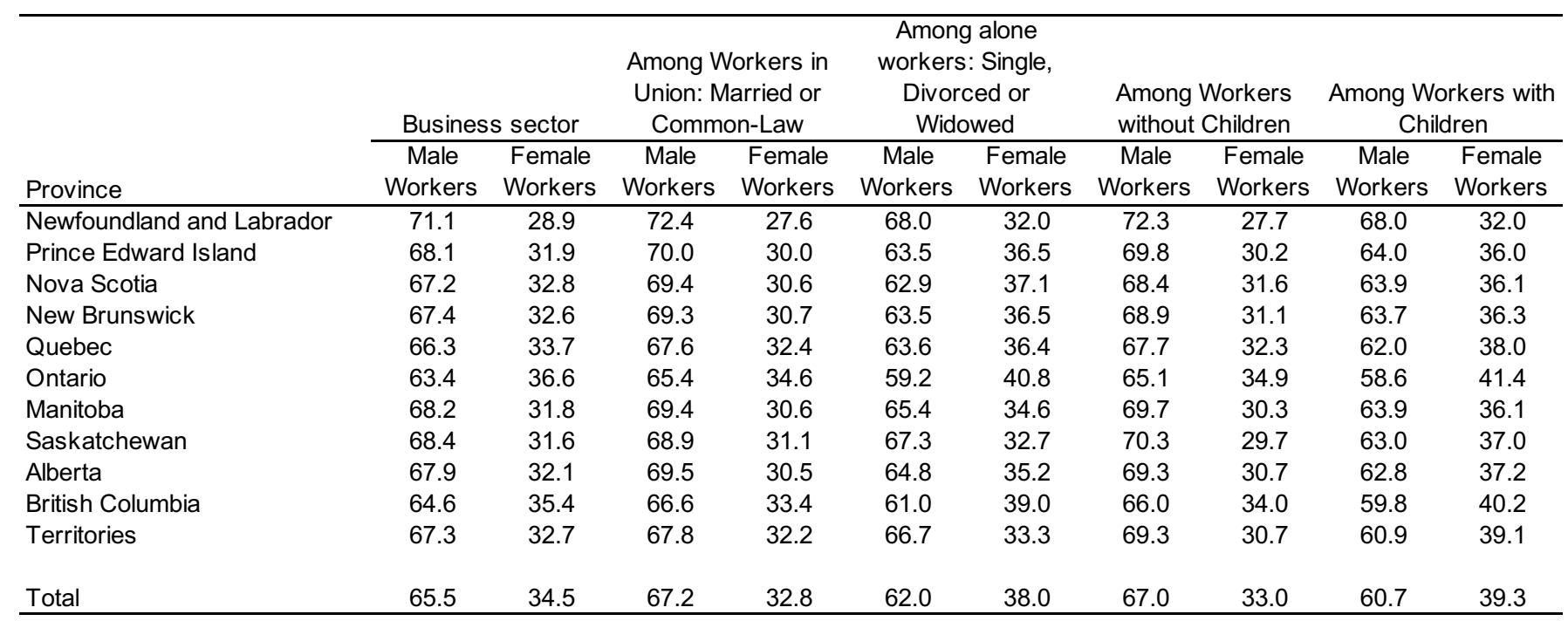

Note: Authors' tabulation of the Canadian Employer-Employee Dynamics Database, 2001-2015. Annual earnings are set to missing if less than roughly $\$ 18,000$ threshold (in 2012 real dollars) -- see text. Marital status is categorized into union (married and common-law) and alone (separated / widowed / divorced and single). Children indicator divides workers into those with children and those without. 


\begin{tabular}{|c|c|c|c|c|c|c|c|c|c|c|}
\hline \multirow[b]{2}{*}{ Industry } & \multicolumn{2}{|c|}{ Business sector } & $\begin{array}{r}\text { Among V } \\
\text { Union: } \\
\text { Comm }\end{array}$ & $\begin{array}{l}\text { orkers in } \\
\text { arried or } \\
\text { on-Law }\end{array}$ & $\begin{array}{r}\text { Amon } \\
\text { workers } \\
\text { Divor } \\
\text { Wid } \\
\end{array}$ & $\begin{array}{l}\text { alone } \\
\text { : Single, } \\
\text { sed or } \\
\text { wed }\end{array}$ & $\begin{array}{l}\text { Among } \\
\text { without }\end{array}$ & $\begin{array}{l}\text { Norkers } \\
\text { Children }\end{array}$ & \multicolumn{2}{|c|}{$\begin{array}{c}\text { Among Workers with } \\
\text { Children }\end{array}$} \\
\hline & $\begin{array}{c}\text { Male } \\
\text { Workers }\end{array}$ & $\begin{array}{c}\text { Female } \\
\text { Workers }\end{array}$ & $\begin{array}{c}\text { Male } \\
\text { Workers }\end{array}$ & $\begin{array}{l}\text { Female } \\
\text { Workers }\end{array}$ & $\begin{array}{c}\text { Male } \\
\text { Workers }\end{array}$ & $\begin{array}{l}\text { Female } \\
\text { Workers }\end{array}$ & $\begin{array}{c}\text { Male } \\
\text { Workers }\end{array}$ & $\begin{array}{l}\text { Female } \\
\text { Workers }\end{array}$ & $\begin{array}{c}\text { Male } \\
\text { Workers }\end{array}$ & $\begin{array}{l}\text { Female } \\
\text { Workers }\end{array}$ \\
\hline Agri., forestry, fishing \& hunting & 81.2 & 18.8 & 81.9 & 18.1 & 79.4 & 20.6 & 83.6 & 16.4 & 73.2 & 26.8 \\
\hline Mining, oil \& gas extraction & 83.2 & 16.8 & 84.5 & 15.5 & 80.4 & 19.6 & 83.2 & 16.8 & 83.3 & 16.7 \\
\hline Utilities & 71.5 & 28.5 & 74.4 & 25.6 & 63.6 & 36.4 & 71.7 & 28.3 & 71.2 & 28.8 \\
\hline Construction & 87.6 & 12.4 & 87.4 & 12.6 & 88.0 & 12.0 & 88.9 & 11.1 & 83.6 & 16.4 \\
\hline Manufacturing & 75.0 & 25.0 & 76.4 & 23.6 & 71.6 & 28.4 & 76.3 & 23.7 & 71.5 & 28.5 \\
\hline Wholesale trade & 68.3 & 31.7 & 70.3 & 29.7 & 63.9 & 36.1 & 69.7 & 30.3 & 64.4 & 35.6 \\
\hline Retail trade & 54.8 & 45.2 & 55.7 & 44.3 & 53.1 & 46.9 & 57.2 & 42.8 & 47.8 & 52.2 \\
\hline Transportation \& warehousing & 73.1 & 26.9 & 75.0 & 25.0 & 69.6 & 30.4 & 74.7 & 25.3 & 68.7 & 31.3 \\
\hline Information \& cultural industries & 58.2 & 41.8 & 61.4 & 38.6 & 52.5 & 47.5 & 59.9 & 40.1 & 52.1 & 47.9 \\
\hline FIRE & 41.0 & 59.0 & 41.7 & 58.3 & 39.4 & 60.6 & 44.0 & 56.0 & 31.9 & 68.1 \\
\hline Prof., sci. \& tech. services & 62.3 & 37.7 & 64.9 & 35.1 & 57.3 & 42.7 & 63.3 & 36.7 & 58.0 & 42.0 \\
\hline Management of companies \& enterprises & 61.1 & 38.9 & 63.3 & 36.7 & 56.6 & 43.4 & 62.7 & 37.3 & 55.8 & 44.2 \\
\hline Admin. \& support, waste mgmt. \& remediation & 58.9 & 41.1 & 60.7 & 39.3 & 56.3 & 43.7 & 61.2 & 38.8 & 50.7 & 49.3 \\
\hline Arts, entertainment \& recreation & 54.2 & 45.8 & 56.2 & 43.8 & 51.6 & 48.4 & 56.7 & 43.3 & 44.9 & 55.1 \\
\hline Accommodation \& food & 49.5 & 50.5 & 50.3 & 49.7 & 48.5 & 51.5 & 52.6 & 47.4 & 38.1 & 61.9 \\
\hline Other services (except public admin.) & 55.2 & 44.8 & 57.7 & 42.3 & 50.6 & 49.4 & 56.3 & 43.7 & 52.0 & 48.0 \\
\hline Total & 65.5 & 34.5 & 67.2 & 32.8 & 62.0 & 38.0 & 67.0 & 33.0 & 60.7 & 39.3 \\
\hline
\end{tabular}

Note: Authors' tabulation of the Canadian Employer-Employee Dynamics Database, 2001-2015. Annual earnings are set to missing if less than roughly $\$ 18,000$ threshold (in 2012 real dollars) -- see text. Marital status is categorized into union (married and common-law) and alone (separated / widowed / divorced and single). Children indicator divides workers into those with children and those without. 
Appendix Table A2.3: Mean gender composition by firm age, 2001-2015 (Percent)

\begin{tabular}{|c|c|c|c|c|c|c|c|c|c|c|}
\hline \multirow[b]{2}{*}{ Firm Age } & \multicolumn{2}{|c|}{ Business sector } & \multicolumn{2}{|c|}{$\begin{array}{l}\text { Among Workers in } \\
\text { Union: Married or } \\
\text { Common-Law }\end{array}$} & \multicolumn{2}{|c|}{$\begin{array}{c}\text { Among alone } \\
\text { workers: Single, } \\
\text { Divorced or } \\
\text { Widowed }\end{array}$} & \multicolumn{2}{|c|}{$\begin{array}{l}\text { Among Workers } \\
\text { without Children }\end{array}$} & \multicolumn{2}{|c|}{$\begin{array}{c}\text { Among Workers with } \\
\text { Children }\end{array}$} \\
\hline & Workers & Workers & Workers & Workers & Workers & Workers & Workers & Workers & Workers & Workers \\
\hline Under 5 years & 66.9 & 33.1 & 68.9 & 31.1 & 63.1 & 36.9 & 68.4 & 31.6 & 63.0 & 37.0 \\
\hline 5 to 9 years & 67.0 & 33.0 & 68.8 & 31.2 & 63.2 & 36.8 & 68.4 & 31.6 & 62.9 & 37.1 \\
\hline Total & 65.4 & 34.6 & 67.2 & 32.8 & 62.0 & 38.0 & 67.0 & 33.0 & 60.7 & 39.3 \\
\hline
\end{tabular}

Note: Authors' tabulation of the Canadian Employer-Employee Dynamics Database, 2001-2015. Annual earnings are set to missing if less than roughly $\$ 18,000$ threshold (in 2012 real dollars) -- see text. Marital status is categorized into union (married and common-law) and alone (separated / widowed / divorced and single). Children indicator divides workers into those with children and those without. 
Appendix Table A2.4: Mean gender composition by firm size, 2001-2015 (Percent)

\begin{tabular}{|c|c|c|c|c|c|c|c|c|c|c|}
\hline Firm Size & $\begin{array}{c}\text { Male } \\
\text { Workers }\end{array}$ & $\begin{array}{c}\text { Female } \\
\text { Workers }\end{array}$ & $\begin{array}{c}\text { Male } \\
\text { Workers }\end{array}$ & $\begin{array}{c}\text { Female } \\
\text { Workers }\end{array}$ & $\begin{array}{c}\text { Male } \\
\text { Workers }\end{array}$ & $\begin{array}{c}\text { Female } \\
\text { Workers }\end{array}$ & $\begin{array}{c}\text { Male } \\
\text { Workers }\end{array}$ & $\begin{array}{c}\text { Female } \\
\text { Workers }\end{array}$ & $\begin{array}{c}\text { Male } \\
\text { Workers }\end{array}$ & $\begin{array}{c}\text { Female } \\
\text { Workers }\end{array}$ \\
\hline 1 to 4 employees & 66.1 & 33.9 & 65.8 & 34.2 & 67.1 & 32.9 & 68.0 & 32.0 & 61.4 & 38.6 \\
\hline 100 to 499 employess & 67.1 & 32.9 & 69.1 & 30.9 & 63.3 & 36.7 & 68.7 & 31.3 & 62.1 & 37.9 \\
\hline 500 or more & 62.7 & 37.3 & 65.1 & 34.9 & 58.0 & 42.0 & 64.1 & 35.9 & 58.5 & 41.5 \\
\hline Total & 65.5 & 34.5 & 67.2 & 32.8 & 62.0 & 38.0 & 67.0 & 33.0 & 60.7 & 39.3 \\
\hline
\end{tabular}

Note: Authors' tabulation of the Canadian Employer-Employee Dynamics Database, 2001-2015. Annual earnings are set to missing if less than roughly $\$ 18,000$ threshold (in 2012 real dollars) -- see text. Marital status is categorized into union (married and commonlaw) and alone (separated / widowed / divorced and single). Children indicator divides workers into those with children and those without. 